Review

\title{
Gut Microbiota and Nonalcoholic Fatty Liver Disease: Insights on Mechanism and Therapy
}

\author{
Junli Ma, Qihang Zhou and Houkai Li* \\ Center for Traditional Chinese Medicine and Systems Biology, Institute for Interdisciplinary Medicine \\ Sciences, Shanghai University of Traditional Chinese Medicine, Shanghai 201203, China; \\ *Correspondence: houkai1976@126.com; Tel.: +86-21-5132-2729
}

\begin{abstract}
Gut microbiota play critical roles in development of obese-related metabolic diseases such as nonalcoholic fatty liver disease (NAFLD), type 2 diabetes, and insulin resistance, which highlighted the potential of gut microbiota-targeted therapies on these diseases. There are various ways that can manipulate gut microbiota including probiotics, prebiotics, synbiotics, antibiotics and some active components from herbal medicines. In this review, we first described the main roles of gut microbiota in mediating the development of NAFLD, and the advances in gut microbiota-targeted therapies in NAFLD in both the experimental and clinical studies, as well as the conclusions on the prospect of gut microbiotatargeted therapies in the future.
\end{abstract}

Keywords: Gut microbiota; obesity; insulin resistance; NAFLD; probiotic; prebiotic; symbiotic

\section{Introduction}

The mammalian gastrointestinal tract is the main site for commensal bacteria. There are over $10^{14}$ microorganisms inside human body [1], which play important roles in maintaining human health [2]. The abundance and composition of gut microbiota are highly variable in the context of different conditions contributing to development of various diseases [3, 4]. In recent years, a huge number of studies have revealed the critical roles of gut microbiota in affecting development of metabolic diseases including type 1 and 2 diabetes [5, 6], obesity [7-10], cardiovascular disease[11-13], and chronic liver diseases[14].

Nonalcoholic fatty liver disease (NAFLD) is a spectrum of chronic liver diseases including simple steatosis, nonalcoholic steatohepatitis (NASH), fibrosis, cirrhosis, and hepatocellular carcinoma (HCC) [9]. NAFLD is the most common chronic liver disease due to the prevalence of obesity worldwide[15]. In addition to the well-established "two-hit" theory [16], the alteration of gut microbiota also promotes the development of NAFLD by mediating processes of inflammation, insulin resistance, bile acids and choline metabolism[17, 18]. As a result, the elucidation on the roles of gut microbiota in NAFLD highlights the significance of gut microbiota-targeted therapies for NAFLD $[19,20]$. There are various ways in manipulating gut microbiota including probiotics, prebiotics, synbiotics, antibiotics and some active components from herbal medicines.

In this review, we comprehensively retrieved the publications on the topics of gut microbiota and NAFLD mainly published within the past 10 years through Pubmed. Based on all of the publications available, we organized this systemic review and first described the main roles of gut microbiota in mediating NAFLD formation. Then, we discussed the status of gut microbiota-targeted therapies in NAFLD in both the experimental and clinical studies, and summarized the prospect of gut microbiota-targeted therapies in the future.

\section{Roles of gut microbiota in NAFLD development}


Since obesity is the common ground of most metabolic diseases, gut microbiota play critical roles in the development of obesity and obese-related metabolic diseases[21]. Gut microbiota mediates the development of obesity by producing certain types of microbial metabolites like short-chain fatty acids (SCFAs) that regulate host energy harvest[22, 23], or modulating signaling pathways of host energy metabolism[24]. Study reveals gut microbiota promote the intestinal absorption of monosaccharides, which accelerate the de novo hepatic lipogenesis and suppress fasting-induced adipocyte factor resulting in the accumulation of triglycerides in adipocytes [25]. More evidence of gut microbiota in affecting host energy metabolism has been acquired in numerous studies [25-27].

Insulin resistance is a basic pathophysiological process of metabolic diseases [28, 29]. In NAFLD, insulin resistance accelerates the fat accumulation and inflammation in hepatocytes[30]. The enhanced inflammation and insulin resistance forms a "vicious cycle" deteriorating the development of NAFLD. The term "metabolic endotoxemia" was coined on the basis of increased lipopolysaccharide (LPS) levels in circulation of metabolic diseases [31], in which LPS combines with LBP (LPS binding protein) and then binds to the CD14/TLR-4 complex triggering an inflammatory reaction and insulin resistance [32-34]. Therefore, the gut dysbiosis is causative for enhanced secretion of LPS and its mediated inflammation in NAFLD development.

Choline not only is an indispensable component of cell membrane phospholipids, but also plays important role in lipids metabolism. Choline facilitates the lipids transport in hepatocytes and prevents the abnormal accumulation of lipids in liver, while choline deficiency usually leads to hepatic steatosis [35, 36]. Gut microbiota also involve in choline metabolism by converting it into toxic dimethylamine and trimethylamine, which are transported to liver and converted into trimethylamine oxide (TMAO) that causes liver inflammation and damage[37]. The increased production of TMAO is also the culprit for cardiovascular disease [37-39]. On the other hand, the content of dietary choline influences the composition and abundance of gut microbiota that are associated with the development of NAFLD [40]. The close relationship between gut microbiota and choline metabolism provides important rationale for gut microbiota-targeted therapy for NAFLD.

Bile acids are synthesized from cholesterol with a wide range of physiological functions. Bile acids can not only facilitate digestion and absorption of fat-soluble food, but also preserve the intestinal barrier and preventing bacterial translocation [41, 42]. Moreover, bile acids could function as signaling molecules that modulate the balance of bile acids metabolism by activating farnesoid X receptor (FXR) and G protein-coupled receptor (TGR5)[43-46]. Study reveals that antibiotics could attenuate the high-fat diet-induced NAFLD development by altering the composition of bile acids and inhibiting FXR signaling pathway, whereas mice with intestine-specific $F x r$ disruption have reduced triglyceride accumulation in the liver compared with control mice [47]. Bile acids usually have strong anti-microbial property and gut microbiota can also influence the homeostasis of bile acids pool by deconjugating and metabolizing the primary bile acids into secondary bile acids in intestinal tract, which are involved in modulating lipids and energy metabolism pathways during NAFLD formation[44]. The crosstalk between gut microbiota and bile acids provides fundamental evidence for gut microbiota-targeted therapy of NAFLD. A schematic view on the roles of gut microbiota on NAFLD formation was summarized in Figure 1. 

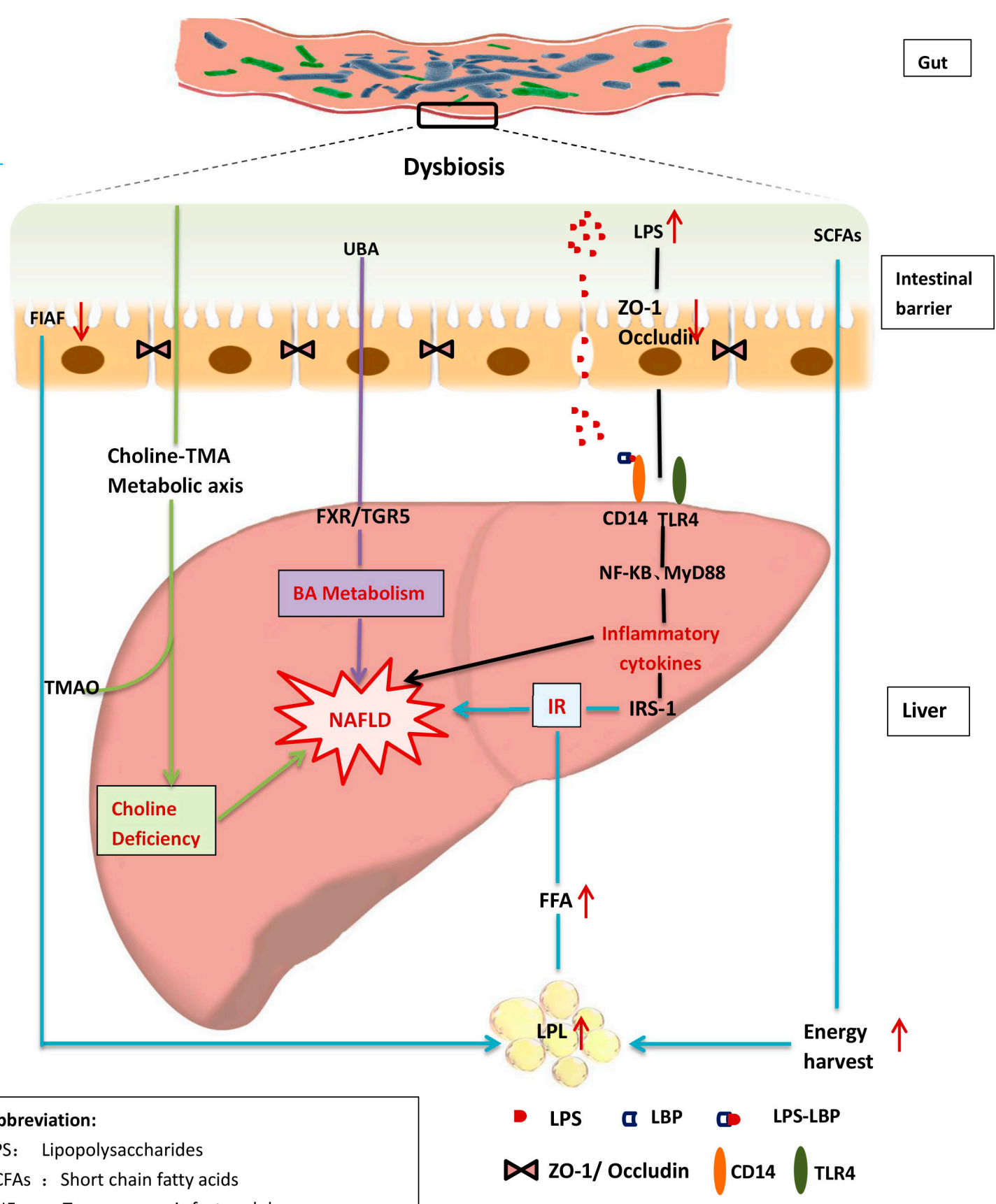

TNF- $\alpha$ : Tumor-necrosis factor alpha

TLR: Toll like receptor

UBA: unconjugated bile acid

ZO-1 \Occludin :Two tight junction proteins

BA: Bile acid

FIAF: Fasting-induced adipocyte factor

NF-kB : Nuclear factor-kB

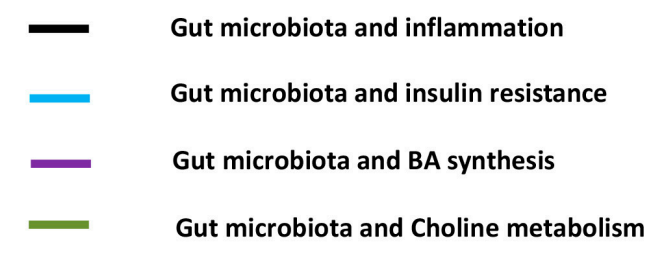

Figure 1 Schematic view on roles of gut microbiota in NAFLD [2, 48-60].

\section{Gut microbiota-targeted therapies of NAFLD}

NAFLD is very common in the context of huge numbers of obese population currently, however, clinical therapeutic options are still very scarce in respect to the safety, effectiveness and patient compliance [61]. As a result, the well-established intricate relationship between gut microbiota and NAFLD opens up a new window for seeking effective and safe therapies of NAFLD by manipulating gut dysbiosis of NAFLD patients with various ways including probiotics, prebiotics, synbiotics and active components from herbal medicines. 


\subsection{Gut microbiota-targeted therapy with probiotic}

Probiotics are a collection of bacteria with a wide range of beneficial effects on host metabolism [2, 62]. Bacteria of Lactobacillus, Bifidobacterium and Satreptococcus are most frequently used probiotics that can inhibit expansion of gram-negative pathogenic bacteria [63]. Okubo $\mathrm{H}$ et al. investigated the effects of Lactobacillus caseistrain Shirota (LcS) on methioninecholine-deficient (MCD) diet-induced NASH mice [64]. They found that MCD diet feeding resulted in significant reduction in lactic acid bacteria (Bifidobacterium and Lactobacillusin) in feces, but were increased by LcS supplement. Moreover, LcS supplement dramatically improved the symptoms of NASH induced by MCD such as hepatic histology, serum parameters (TG, TC, ALT), as well as the altered expression of hepatic genes and proteins (the mRNA levels of $\alpha$-SMA and TIMP-1). Meanwhile, metabolic beneficial effects of LcS supplement were observed in High-fat diet (HFD)-induced and genetic $d b / d b$ obese mice, in which LcS supplement significantly improved insulin resistance and lowered plasma levels of LBP [65]. Study revealed that LcS treatment protected against the fructose-induced NAFLD by suppressing the activation of Toll-like receptor (TLR) 4 signaling cascade in the liver [66]. Accordingly, the beneficial effect of LcS in metabolic diseases is associated with the reduction of metabolic endotoxaemia.

Lactobacillus is a genus of gram-positive bacteria which can convert sugars into lactic acid. Bacteria from Lactobacillus genus have been trialed as probiotics in a variety of studies [67-69]. Sohn W et al. investigated the effects of Lactobacillus paracasei (L.paracasei ) on NASH patients [70], they found that L.paracasei administration lowered inflammatory cytokines in NASH patients, but probiotics with single species of Lactobacillus bacteria did not show benefit in patients with irritable bowel syndrome or Crohn's disease[71, 72], suggesting variable effects of probiotic in different diseases and combined probiotics with different species of Lactobacillus bacteria are necessary. Meanwhile, the beneficial effects of some Lactobacillus plantarum probiotics were investigated on NAFLD models including L. plantarumMA2, L.plantarumA7 and L.plantarumNCU116. Results showed that probiotic of L. plantarumA7 was effective in lowering serum lipids on rats[73]. Administration of L. plantarumMA2 could reduce serum total cholesterol, low-density lipoprotein cholesterol, and triglycerides levels [74], while L.plantarumNCU116 improved liver function and decreased hepatic fat accumulation as well [75]. Similarly, probiotic of L.rhamnosus bacteria showed beneficial effect on NAFLD model. Studies indicated that L. rhamnosus GG (LGG) protected mice from NAFLD by increasing the abundance of beneficial bacteria, improving gut barrier function and attenuating hepatic inflammation [76], as well as the cholesterol-lowering effect through inhibition of FXR and FGF15 signaling pathway [77]. In addition, several other species of Lactobacilli bacteria have shown potential as probiotics because of observed benefits in NAFLD prevention including $L$. johnsonii BS15 [78], L.reuteri GMNL-263[79], L. gasseri BNR17[80].

Bifidobacterium (Bif) belongs to Bifidobacteria bacteria that are one of the major genera inhabited in mammalian gastrointestinal tract. Bif is a frequently used probiotic [81-83]. Supplement of probiotic Bif significantly improved visceral fat accumulation and insulin sensitivity in HFD fed rats [84]. Moreover, administration of Bifidobacterium pseudocatenulatum CECT 7765 reduced serum cholesterol, triglyceride, and improved glucose tolerance in obese mice [85]. It is proposed that probiotic of Bif is superior to Lactobacillus acidophilus in reducing hepatic fat accumulation [86].

Compared to probiotic with single strain of bacteria, VSL\#3 is a mixed probiotic with eight types of bacteria (Bifidobacteria [B. breve, B. longum, B.infantis], Streptococcus thermophilus, L. plantarum, L. acidophilus, L. paracasei and L. delbrueckii subsp. bulgaricus) which has shown great potential in treatment various diseases [87-91]. Experimental evidence have indicated that administration with probiotic of VSL \#3 attenuated inflammation via modulating NF-kB pathway [92], reduced hepatic fat accumulation and ALT levels [93], improved insulin 
sensitivity in NAFLD models[94], as well as prevention against liver fibrosis in NASH[95]. The probiotic with combined bacteria (LGG, Lactobacillus plantarum WCFS1 and anthraquinone from cassia obtusifolia L.) also effectively reduced blood lipid levels and improved insulin resistance in NAFLD rats [96]. Meanwhile, supplementation of combined probiotic (Bifidobacterium infantis, Lactobacillus acidopilus and Bacillus cereus) could improve gut dysbiosis and liver function via suppression on LPS/TLR4 signaling pathway [97]. Kim DH et al. found that consumption of kefir (a probiotic beverage containing over 50 species of lactic acid bacteria and yeast) prevented obesity and NAFLD formation by restoring gut microbiota and enhancing fatty acid oxidation in HFD-fed mice[98]. Further evidence of beneficial effects on NAFLD prevention has been acquired in many studies by administering probiotics of mixed bacteria [99-101]. In addition to the direct impacts on the composition of gut microbiota, the beneficial effects of probiotics on NAFLD are also associated with their metabolic activities [53]. It has been reported that probiotic of MIYAIRI 588-a butyrate-producing bacteria decreased accumulation of lipid droplets in HFD-induced NAFLD models and improved insulin resistance[102], reduced hepatic lipids and serum endotoxin levels in choline-deficient/Lamino acid-defined diet induced NAFLD models [103], which may be associated with the stimulation on expression of AMPK and AKT proteins, and lipogenesis- or lipolysis-related proteins.

Currently, although the beneficial effects of probiotics were mainly acquired in experimental studies, some consistent results have also been observed in clinic. Alisi et al. compared the therapeutic effects of VSL\#3 in a randomized double-blind RCT study in obese children with biopsy-proven NAFLD. They found that 4-month supplement of VSL\#3 significantly improved the liver function and increased GLP-1/ aGLP1 levels suggesting the beneficial effects of VSL\#3 might be GLP-1-dependent [104]. Similarly, consistently beneficial effects were also observed on children with obesity and NAFLD by administering probiotics such as Lactobacillus rhamnosus strain GG [105] and mixed bacteria of Lactobacillus bulgaricus and Streptococcus thermophilus [106]. Sepideh, A et al. investigated the effects of a multistrain probiotic supplementation in NAFLD patients in a RCT study[107], and the results showed dramatic improvement in insulin sensitivity and inflammation. Moreover, synergistic effects were also observed by combining probiotics with chemical drugs such as metformin in NASH and statins in NAFLD therapy [108, 109], which highlights the great potential of clinical application of probiotics either alone or combined with other drugs. Nevertheless, the clinical efficacy of probiotics still needs further validation in well-designed studies with larger scale of participants because of the some discrepant results among different studies. For instance, Solga et al. hypothesized that probiotics would reduce hepatic steatosis in humans[110]. However, at the end of 4 months, all 4 subjects behaved a significant increase in liver fat, which indicated the opposite trend compared with the initial assumptions. They concluded that the most important limitation in this study was the small number of study subjects. In 2010, Andreasen AS et al. conducted a randomized-double-blinded research about effects of L.acidophilus NCFM on insulin sensitivity and the systemic inflammatory response[111]. In the probiotic group, insulin sensitivity was preserved among volunteers, while it decreased in the placebo group, and there were no changes in both baseline inflammatory markers and the systemic inflammatory response after interventions. In another study, scientists found that probiotic capsules did not have significant effects on lipid markers of T2DM patients. It showed that there are no significant changes in total cholesterol, low-density lipoprotein (LDL)-cholesterol, high-density lipoprotein (HDL)-cholesterol, Triglycerides (TG), TG/LDL and LDL/HDL ratios after 8-week probiotic supplementation[112]. Additionally, in a double-blind placebocontrolled study, the effects of Lactobacillus acidophilus on plasma lipids was also studied in volunteers with elevated cholesterols. There were no changes in serum lipids seen throughout the study[113]. 


\subsection{Gut microbiota-targeted therapy with prebiotic}

Prebiotic is the collection of nondigestible food ingredients that beneficially affect the host by selectively stimulating the growth and/or activity of bacteria resident in the colon and improving host health [114], or defined as selectively fermented ingredient that allows specific changes, both in the composition and/or activity in the gastrointestinal microflora conferring benefits upon host well-being and health [115]. Prebiotics exert benefits on host health by altering gut microbiota [116], and several lines of evidence have demonstrated that prebiotics benefits NAFLD prevention by modulating gut microbiota in both experimental and clinical studies $[117,118]$.

In 2009, Cani et al. found that prebiotic of oligofructose (a mixture of fermentable dietary fibers) decreased plasma LPS and cytokines levels, and hepatic expression of inflammatory and oxidative stress markers in genetic obese mice, as well as improvement in intestinal permeability and production of GLP-2[119]. In methionine-choline-deficient diet-induced steatohepatitis mice model, dietary fructooligosaccharides (FOS) supplementation attenuated the extent of steatohepatitis by restoring the homeostasis of gut microbiota and intestinal epithelial barrier function [120]. Barbara D et al. reported that FOS supplement reduced hepatic triglyceride accumulation in n-3 PUFA-depleted diet-induced NAFLD model by altering microbiota composition and increasing production of GLP-1[121]. Meanwhile, FOS supplementation stimulated fatty acid oxidation by activating peroxisome proliferatoractivated receptor-alpha (PPAR- $\alpha$ ) and reduced cholesterol accumulation by inhibiting SREBP2 in liver without affecting SREBP-1 expression and activity [121, 122]. Lactulose is a prebiotic that promotes the growth of lactic acid bacteria and Bifidobacteria [123]. Study indicated that Lactulose treatment decreased the hepatic inflammation and serum endotoxin levels in rats with steatohepatitis [124]. Chitin-glucan (CG) is another type of prebiotic from fungal source. Neyrinck AM et al. investigated the function of CG in HFD-induced obese mice and found CG treatment decreased body weight gain, improved glucose intolerance and hepatic triglyceride accumulation by restoring bacteria from clostridial cluster XIVa [125].

The combination of prebiotic with natural components will yield more benefits than itself. For example, combined therapy of prebiotic of isomalto-oligosaccharides (IMOs) with lycopene (an antioxidant) prevented body weight gain, enhanced adipose tissue fat mobilization and improved insulin resistance and metabolic endotoxemia in HFD-induced NAFLD mice. Moreover, the observed benefits may be associated with their modulation on gut microbiota and production of SCFA [126].

In clinic, prebiotics have also been trialed for their benefits in various diseases [127-131]. Oligofructose (OFS), an inulin-type fructans, were added to diet for patients with NASH in a pilot randomized double-blind study [118]. The results showed that OFS supplementation decreased serum ALT and AST levels significantly compared to that in placebo group. Prebiotics of mixed galacto-oligosaccharides and fructo-oligosaccharides (9:1) also showed stimulating effect on abundance of Bifidobacteria bacteria in infants [132]. Similarly, administration of prebiotic inulin and oligofructose (50:50 in mixture) increased abundance of Bifidobacterium and Faecalibacterium prausnitzii, which negatively correlated with serum LPS levels [133]. Accordingly, prebiotics have shown great potential in prevention of obesity and NAFLD development by lowering the permeability of intestinal wall, attenuating metabolic endotoxemia, and reducing the accumulation of fat [134].

\subsection{Gut microbiota-targeted therapy with symbiotic}

Synbiotic is the combination of probiotics and prebiotics [135]. Synbiotic usually yields benefits by selectively stimulating the growth and/or activating the metabolism of healthpromoting bacteria[136]. Administration of synbiotic production containing Lactobacillus paracasei B21060 plus arabinogalactan and fructooligosaccharides attenuated hepatic inflammation and increased expression of nuclear PPARs and their targeted genes in HFD- 
induced NAFLD rats [137]. Synbiotics have shown various benefits in metabolic diseases such as improvement of IR, glucose control, and inflammatory cytokines synthesis [138-140].

In the clinic, the therapeutic effect of a synbiotic containing seven probiotics and oligofructose was evaluated on patients with NAFLD in a double-blind RCT. The results showed that synbiotic therapy significantly decreased ALT levels compared to that in placebo group [141]. Malaguarnera et al. revealed that therapy with synbiotic ( B. longum and Fos) and lifestyle intervention in NASH patients produced much more improvement compared lifestyle intervention alone including reduction of serum TNF $\alpha$, CRP, endotoxin and AST levels, improvement in HOMA-IR and extent of NASH activity index[142]. Synbiotic therapy also showed improvement in levels of fasting blood glucose, TG and inflammatory cytokines in NAFLD patients $[143,144]$. Therefore, symbiotic is one of the promising gut microbiotatargeted interventions on NAFLD prevention or therapy, nevertheless, the therapeutic efficacy needs further clinical validation.

\subsection{Gut microbiota-targeted therapies with other approaches}

In addition to the well-established impacts of probiotic/prebiotic/synbiotic on gut microbiota, gut microbiota-targeted interventions have also been investigated with other approaches. Butyrate belongs to SCFAs and is an important gut microbial metabolite derived from fermentation of nondigestible polysaccharides. Butyrate has been demonstrated with critical role in affecting metabolic diseases development through a variety of ways including modulation of energy harvest, hepatic lipogenesis and gluconeogenesis, adipokine signaling in adipocytes, intestinal permeability and appetite regulation in brain[145, 146]. Research showed that administration of sodium butyrate alleviated inflammation and fat accumulation in HFD-induced NAFLD mice by increasing the abundances of the beneficial bacteria Christensenellaceae, Blautia and Lactobacillus [147]. Therefore, appropriate approaches such as engineered bacteria could be developed to enhance the production of beneficial gut microbial metabolites (i.g butyrate) or intervention with chemical drugs to promote the proliferation of "good" bacteria, but suppress the "bad" ones.

Antibiotic is one of the most frequently used medicines in clinic. In addition to their direct antibacterial effects, the consequences of disrupting the gut microbial homeostasis have been increasingly valued [148]. Interestingly, oral administration with cidomycin increased the small intestine transit rate and lowered serum ALT, AST and TNF- $\alpha$ levels in NASH rats suggesting the potential of cidomycin in alleviating the severity of NASH by intervening gut microbiota [149]. In the clinic, administration of rifaximin could decrease the circulating endotoxin and ALT levels in patients with NAFLD [150]. Although the improvement in NAFLD, especially in NASH by short-term administration of antibiotic is observed (i. $g$ rifaximin), the long-term application of antibiotics is not encouraged because of probable side effects [151].

Compared to gut microbiota modulation with antibiotic, some ingredients from herbal medicines have shown effects on gut microbiota with minor side effects [152, 153]. Berberine is a typical herbal component with potent antibacterial activity, especially bacteria in intestinal tract because berberine can hardly be absorbed in gut [154]. Currently, increasing evidence has confirmed the therapeutic effect of berberine on metabolic diseases including obesity, NAFLD, and type 2 diabetes via modulation on gut microbiota [155-157]. It has been revealed that berberine administration restored the relative abundance of Bifidobacteria and the ratio of Bacteroidetes / Firmicutes in HFD-induced NASH mice resulting in significant reduction in body weight, serum levels of lipids, glucose, insulin and inflammatory cytokines [158, 159]. TSG (2, $3,5,4^{\prime}$-tetrahydroxy-stilbene-2-O- $\beta$-D-glucoside) is an active component from Traditional Chinese Medicine (TCM) Polygonum multiflorum Thunb, which has shown significant effect on NAFLD prevention by modulating gut microbiota, improving the intestinal mucosal barrier and suppressing the expression of NF- $\mathrm{BB}$ [160]. Resveratrol belongs to natural polyphenols 
with classical anti-oxidative activity [161]. Recent studies showed resveratrol was also effective in preventing metabolic diseases such as obesity and NASH by regulating gut microbiota [162]. In addition to the components from herbal medicines, several recent investigations have revealed that the efficacy of some TCM formula was associated with the modulation on gut microbiota. For example, Qushi Huayu Fang (a mixture of five herbs including Artemisia capillaries Thunb, Gardenia jasminoides Ellis, Fallopia japonica, Curcuma longa L., and Hypericum japonicum Thunb) is an ancient TCM formula which has been used for NAFLD treatment. Recent studies showed that administration of Qushi Huayu Decoction (QHD) significantly decreased body weight, alleviated hepatic steatosis, and reduced the content of TG and free fatty acids in liver in HFD-induced NAFLD rats. It showed that the CHF-treated group harbored significantly different gut microbiota from that of model rats, and the bacterial profiles of NAFLD rats could be modulated by the CHF $[163,164]$. Recently, the anti-obesity property of daesiho-tang (DSHT) was also investigated. It was found that DSHT treatment significantly reduced serum TC and TG and hepatic fat accumulation which were associated with the regulation on abundance of gut microbiota [165]. Although the mechanisms underlying TCM are extremely complicated and largely unknown, gut microbiota was important target for many TCM formulas because many kinds of chemicals within TCM are unabsorbable that can influence gut microbiota directly or be metabolized into active form by gut microbiota. A detailed summary of gut microbiota-targeted therapies on NAFLD were provided in Table 1.

Table1. Gut microbiota-targeted therapies of NAFLD

\begin{tabular}{|c|c|c|c|c|}
\hline \multicolumn{2}{|c|}{ Interventions } & Main effects & Experimental Models & Ref. \\
\hline & \multirow{3}{*}{$\begin{array}{l}\text { Lactobacillus } \\
\quad \text { (LcS) }\end{array}$} & $\begin{array}{l}\text { Suppressing NASH } \\
\text { development }\end{array}$ & $\begin{array}{l}\text { MCD diet-induced NASH in } \\
\text { mice }\end{array}$ & {$[64]$} \\
\hline & & $\begin{array}{c}\text { Improving insulin resistance and } \\
\text { glucose intolerance }\end{array}$ & $\begin{array}{l}\text { Diet-induced obesity (DIO) } \\
\text { mice. }\end{array}$ & [65] \\
\hline & & $\begin{array}{l}\text { Protecting against the } \\
\text { onset of fructose-induced } \\
\text { NAFLD }\end{array}$ & $\begin{array}{l}\text { Fructose-induced NAFLD in } \\
\text { mice }\end{array}$ & [66] \\
\hline & L.paracasei & $\begin{array}{l}\text { Attenuating hepatic } \\
\text { steatosis }\end{array}$ & $\begin{array}{c}(\mathrm{HF}+10 \% \text { fructose diet)-induced } \\
\text { NASH in mice }\end{array}$ & {$[70]$} \\
\hline & L. plantarumA7 & $\begin{array}{c}\text { Lowering serum lipid, TC and } \\
\text { TG levels }\end{array}$ & High cholesterol diet fed rats & {$[73]$} \\
\hline & $\begin{array}{c}\text { L. } \\
\text { plantarumMA2 }\end{array}$ & $\begin{array}{c}\text { Lowering serum TC, TG and } \\
\text { lowdensity lipoprotein } \\
\text { cholesterol }\end{array}$ & $\begin{array}{l}\text { Cholesterol-enriched diet fed } \\
\text { rats }\end{array}$ & [74] \\
\hline & $\begin{array}{l}\text { L.plantarum } \\
\text { NCU116 }\end{array}$ & $\begin{array}{c}\text { Improving liver function, } \\
\text { oxidative stress and lipid } \\
\text { metabolism }\end{array}$ & HFD-induced NAFLD in rats & [75] \\
\hline \multirow{3}{*}{ Probiotic } & \multirow{3}{*}{$\begin{array}{l}\text { Lactobacillus } \\
\text { rhamnosusGG } \\
\text { (LGG) }\end{array}$} & $\begin{array}{c}\text { Protecting mice from NAFLD } \\
\text { attenuated liver inflammation } \\
\text { and steatosis }\end{array}$ & $\begin{array}{l}\text { High-fructose diet induced } \\
\text { NAFLD in mice }\end{array}$ & [76] \\
\hline & & Improving NAFLD & HFD-induced NAFLD in rats & [82] \\
\hline & & $\begin{array}{l}\text { An improveent in alanine } \\
\text { aminotransferase }\end{array}$ & $\begin{array}{l}20 \text { obesity-related liver } \\
\text { abnormalities children }\end{array}$ & [105] \\
\hline
\end{tabular}




\begin{tabular}{|c|c|c|c|}
\hline L.johnsonii BS15 & Effective in preventing NAFLD & HFD-induced NAFLD in mice & {$[78]$} \\
\hline $\begin{array}{c}\text { L.reuteri } \\
\text { GMNL-263 }\end{array}$ & Ameliorating hepatic steatosis & High-fructose diet fed rats & [79] \\
\hline $\begin{array}{l}\text { L. gasseri } \\
\text { BNR17 }\end{array}$ & $\begin{array}{l}\text { Inhibiting increases in body and } \\
\text { adipocyte tissue weight }\end{array}$ & $\begin{array}{l}\text { High-sucrose diet-induced } \\
\text { obese mice. }\end{array}$ & {$[80]$} \\
\hline $\begin{array}{l}3 \text { Lactobacillus } \\
\text { strains }\end{array}$ & $\begin{array}{c}\text { Reducing serum TC, TG and } \\
\text { low-density lipoprotein } \\
\text { cholesterol }\end{array}$ & HFD fed rats & [166] \\
\hline $\begin{array}{l}\text { L. } \\
\text { acidophilus NC } \\
\text { FM }\end{array}$ & $\begin{array}{l}\text { Inflammatory markers and the } \\
\text { systemic inflammatory response } \\
\text { were unaffected }\end{array}$ & 45 males with T2DM & [111] \\
\hline L. acidophilus & No changes in serum lipids & $\begin{array}{l}80 \text { patients with elevated } \\
\text { cholesterols }\end{array}$ & [113] \\
\hline \multirow{3}{*}{$\begin{array}{l}\text { Bifidobacterium } \\
\text { (Bif) }\end{array}$} & $\begin{array}{l}\text { Ameliorating visceral fat } \\
\text { accumulation and insulin } \\
\text { sensitivity }\end{array}$ & HFD fed rats & {$[84]$} \\
\hline & $\begin{array}{l}\text { Attenuating hepatic fat } \\
\text { accumulation }\end{array}$ & HFD-induced NAFLD in rats & {$[86]$} \\
\hline & $\begin{array}{c}\text { Reducing body and fat weights, } \\
\text { blood serum levels (TC, HDL-C, } \\
\text { LDL-C, TG, AST, ALT, and } \\
\text { lipase levels) }\end{array}$ & HFD induced obesity rats & [167] \\
\hline $\begin{array}{l}\text { B.pseudocatenul } \\
\text { atum CECT } \\
7765 \\
\end{array}$ & $\begin{array}{l}\text { Reducing serum cholesterol, } \\
\text { TG, and insulin resistance }\end{array}$ & HFD fed mice & {$[85]$} \\
\hline $\begin{array}{c}\text { Bacteroides } \\
\text { uniformis CECT } \\
7771\end{array}$ & $\begin{array}{l}\text { Reducing body weight gain, } \\
\text { liver steatosis and cholesterol } \\
\text { and TG concentrations }\end{array}$ & HFD induced obesity mice & [168] \\
\hline \multirow{7}{*}{ VSL\#3 } & $\begin{array}{c}\text { Limiting oxidative and } \\
\text { inflammatory liver damage }\end{array}$ & HFD fed young rats & {$[92]$} \\
\hline & $\begin{array}{l}\text { Reducing hepatic total fatty acid } \\
\text { content and ALT levels. }\end{array}$ & HFD-induced NAFLD in mice & [93] \\
\hline & $\begin{array}{l}\text { Improvements in steatosis and } \\
\text { insulin resistance }\end{array}$ & HFD fed mice & {$[94]$} \\
\hline & $\begin{array}{l}\text { Modulating liver fibrosis but } \\
\text { don't protecting from } \\
\text { inflammation and steatosis in } \\
\text { NASH. }\end{array}$ & $\begin{array}{l}\text { MCD diet-induced NASH in } \\
\text { mice. }\end{array}$ & [95] \\
\hline & $\begin{array}{l}\text { Improving the degree of liver } \\
\text { disease in children }\end{array}$ & 44 Obese children with NAFLD & [104] \\
\hline & $\begin{array}{c}\text { Improving plasma levels of } \\
\text { lipid peroxidation markers: } \\
\text { MDA, 4-HNE. }\end{array}$ & $\begin{array}{c}22 \text { patients with NAFLD }+20 \\
\text { patients with AC }\end{array}$ & [169] \\
\hline & $\begin{array}{c}\text { Experiencing a significant } \\
\text { increase in liver fat ; no } \\
\text { significant differences in any of }\end{array}$ & 4 patients with NAFLD & [110] \\
\hline
\end{tabular}




\begin{tabular}{|c|c|c|c|}
\hline & $\begin{array}{l}\text { the blood assays or clinical } \\
\text { parameters }\end{array}$ & & \\
\hline & Improving NAFLD & HFD-induced NAFLD in rats & [96] \\
\hline & $\begin{array}{l}\text { Delaying the progression of } \\
\text { NAFLD via LPS/TLR4 signaling }\end{array}$ & $\begin{array}{l}\text { HSHF diet-induced NAFLD in } \\
\text { rats }\end{array}$ & [97] \\
\hline & $\begin{array}{c}\text { Improving NAFLD pathogenesis } \\
\text { and steatosis }\end{array}$ & $\begin{array}{l}\text { High fat and sucrose diet } \\
\text { (HFSD)-induced NAFLD in rats }\end{array}$ & {$[170]$} \\
\hline & $\begin{array}{l}\text { Influencing protein expression } \\
\text { and decreasing steatohepatitis }\end{array}$ & $\begin{array}{l}\text { MCD diet-induced NASH in } \\
\text { rats }\end{array}$ & [99] \\
\hline \multirow{7}{*}{$\begin{array}{l}\text { Probiotic } \\
\text { mixtures }\end{array}$} & $\begin{array}{l}\text { Reducing obesity-related } \\
\text { biomarkers and modulating the } \\
\text { microbial community }\end{array}$ & Obese mice & [100] \\
\hline & $\begin{array}{l}\text { Modulating gut microbiota and } \\
\text { up-regulated genes related to } \\
\text { fatty acid oxidation in both the } \\
\text { liver and adipose tissue }\end{array}$ & HFD-induced obese mice & {$[98]$} \\
\hline & $\begin{array}{c}\text { Improving liver } \\
\text { aminotransferases levels }\end{array}$ & 30 patients with NAFLD & [106] \\
\hline & $\begin{array}{l}\text { Decreasing levels of ALT and } \\
\text { AST and improving pediatric } \\
\text { NAFLD }\end{array}$ & 64 obese children with NAFLD & [171] \\
\hline & $\begin{array}{l}\text { Reducing insulin, insulin } \\
\text { resistance, TNF-a, and IL-6 }\end{array}$ & 42 patients with NAFLD & [107] \\
\hline & $\begin{array}{c}\text { No significant changes in (LDL)- } \\
\text { cholesterol, (HDL)- } \\
\text { cholesterol,TG,TC TG/LDL and } \\
\text { LDL/HDL ratios }\end{array}$ & 60 patients with T2DM & [112] \\
\hline & $\begin{array}{l}\text { Great reductions in serum AST } \\
\text { level and liver fat }\end{array}$ & 20 patients with NASH & [172] \\
\hline \multirow[b]{2}{*}{ MIYAIRI 588} & $\begin{array}{c}\text { Improving NAFLD and } \\
\text { decreasing accumulation of lipid } \\
\text { droplets }\end{array}$ & HFD-induced NAFLD in rats & [102] \\
\hline & $\begin{array}{l}\text { Improving hepatic lipid } \\
\text { deposition and decreasing the } \\
\text { triglyceride content, insulin } \\
\text { resistance, serum endotoxin } \\
\text { levels, and hepatic inflammatory } \\
\text { indexes. }\end{array}$ & $\begin{array}{l}\text { Choline-deficient/L-aminoacid- } \\
\text { defined(CDAA)-diet-induced } \\
\text { NAFLD in rats }\end{array}$ & [103] \\
\hline $\begin{array}{l}\text { Probiotics and } \\
\text { Metformin }\end{array}$ & $\begin{array}{c}\text { Improvements in liver } \\
\text { aminotransferases, cholesterol } \\
\text { and TG }\end{array}$ & 64 patients with $\mathrm{NASH}$ & {$[108]$} \\
\hline
\end{tabular}




\begin{tabular}{|c|c|c|c|c|}
\hline \multirow{3}{*}{ probiotic } & $\begin{array}{l}\text { Probiotics and } \\
\text { statins }\end{array}$ & $\begin{array}{l}\text { Lowering cholesterol and } \\
\text { products of metabolism of } \\
\text { intestinal microflora }\end{array}$ & Patients with NAFLD & [109] \\
\hline & \multirow[t]{2}{*}{ Probiotic yogurt } & $\begin{array}{l}\text { Improving hepatic enzymes, } \\
\text { serum TC, and low-density } \\
\text { lipoprotein cholesterol levels }\end{array}$ & 72 patients with NAFLD & {$[173]$} \\
\hline & & $\begin{array}{l}\text { Improvements in total } \\
\text { cholesterol and LDL-C } \\
\text { concentrations }\end{array}$ & $\begin{array}{c}60 \text { people with type } 2 \text { diabetes } \\
\text { and low-density lipoprotein } \\
\text { cholesterol }\end{array}$ & {$[174]$} \\
\hline \multirow{9}{*}{ Prebiotic } & \multirow[t]{2}{*}{$\begin{array}{l}\text { Oligofructose } \\
\text { (OFS) }\end{array}$} & $\begin{array}{l}\text { Exhibiting a lower LPS and } \\
\text { cytokines, and decreasing } \\
\text { hepatic expression of } \\
\text { inflammatory and oxidative } \\
\text { stress markers }\end{array}$ & Obese and diabetic mice & [119] \\
\hline & & $\begin{array}{l}\text { Decreasing serum ALT, AST } \\
\text { and insulin level }\end{array}$ & Patients with NASH & {$[118]$} \\
\hline & \multirow[t]{2}{*}{$\begin{array}{l}\text { Fructooligosacc } \\
\text { harides (FOS) }\end{array}$} & $\begin{array}{c}\text { Restoring normal } \\
\text { gastrointestinal microflora and } \\
\text { intestinal epithelial barrier } \\
\text { function, and decreasing } \\
\text { steatohepatitis }\end{array}$ & $\begin{array}{l}\text { MCD diet-induced NASH in } \\
\text { mice. }\end{array}$ & {$[120]$} \\
\hline & & $\begin{array}{c}\text { Reducing hepatic TG and TC } \\
\text { level, modulating hepatic } \\
\text { steatosis }\end{array}$ & $\begin{array}{l}\text { N-3PUFA-depleted diet-fed } \\
\text { mice }\end{array}$ & [121] \\
\hline & Lactulose & $\begin{array}{l}\text { Ameliorating the hepatic } \\
\text { inflammation and decreasing } \\
\text { serum levels of ALT and AST }\end{array}$ & HFD-induced NASH in rats & {$[124]$} \\
\hline & $\begin{array}{l}\text { Chitin-glucan } \\
\text { (CG) }\end{array}$ & $\begin{array}{c}\text { Decreasing weight gain, fat mass } \\
\text { development, glucose } \\
\text { intolerance, and hepatic TG } \\
\text { accumulation }\end{array}$ & HFD-induced obese mice & [125] \\
\hline & $\begin{array}{l}\text { Isomalto- } \\
\text { oligosaccharides } \\
\text { (IMOs) }\end{array}$ & $\begin{array}{l}\text { Preventing weight gain, } \\
\text { adiposity, and improving insulin } \\
\text { resistance. }\end{array}$ & HFD-induced NAFLD in mice & {$[126]$} \\
\hline & $\begin{array}{c}\text { Galacto- } \\
\text { oligosaccharides } \\
\text { and fructo- } \\
\text { oligosaccharides } \\
(9: 1) \\
\end{array}$ & $\begin{array}{l}\text { Increasing abundance and } \\
\text { proportion of bifidobacteria }\end{array}$ & Formula-fed infants (FF) & {$[132]$} \\
\hline & $\begin{array}{l}\text { ITF prebiotics } \\
\text { (inulin+oligofru } \\
\text { ctose) }\end{array}$ & $\begin{array}{l}\text { Changing the gut microbiota } \\
\text { composition and host } \\
\text { metabolism }\end{array}$ & 30 obese women & [133] \\
\hline
\end{tabular}




\begin{tabular}{|c|c|c|c|c|}
\hline \multirow{5}{*}{ Synbiotic } & $\begin{array}{l}\text { L.paracasei } \\
\text { B21060+ } \\
\text { arabinogalactan } \\
\quad+\text { FOS }\end{array}$ & $\begin{array}{l}\text { Lessening NAFLD progression, } \\
\text { preserving gut barrier integrity } \\
\text { and reducing the severity of } \\
\text { liver injury and IR }\end{array}$ & HFD-induced NAFLD in rats & [137] \\
\hline & $\begin{array}{l}\text { Seven probiotics } \\
+ \text { OFS }\end{array}$ & $\begin{array}{c}\text { Improving NAFLD and } \\
\text { decreasing levels of ALT and } \\
\text { AST }\end{array}$ & 52 patients with NAFLD & [141] \\
\hline & B.longum + FOS & $\begin{array}{c}\text { Reductions in TNF-a, serum AST } \\
\text { levels, serum endotoxin, } \\
\text { steatosis, and the NASH activity } \\
\text { index }\end{array}$ & 66 patients with NASH & [142] \\
\hline & $\begin{array}{l}\text { Dietary fiber+ } \mathrm{L} . \\
\text { reuteri }\end{array}$ & $\begin{array}{l}\text { Improving NAFLD and } \\
\text { reducing serum levels of most of } \\
\text { the inflammatory mediators }\end{array}$ & 50 patients with NAFLD & [143] \\
\hline & $\begin{array}{c}\text { Seven } \\
\text { probiotics + FOS }\end{array}$ & $\begin{array}{l}\text { Protecting against NAFLD } \\
\text { progression and improving } \\
\text { steatosis }\end{array}$ & 80 NAFLD patients & [144] \\
\hline \multirow{3}{*}{ Aantibiotic } & Cidomycin & $\begin{array}{l}\text { Lowering serum levels of ALT, } \\
\text { AST and TNF- } \alpha \text { and alleviating } \\
\text { the severity of NASH }\end{array}$ & Rats with NASH & [149] \\
\hline & $\begin{array}{l}\text { Vancomycin+Ne } \\
\text { omycin+Metron } \\
\text { idazole+Ampicil } \\
\quad \operatorname{lin}\end{array}$ & $\begin{array}{l}\text { Adjusting gut microecology and } \\
\text { alleviating the lesions of NAFLD }\end{array}$ & HFD-induced NAFLD in rats & [175] \\
\hline & Rifaximin & $\begin{array}{l}\text { Improving NAFLD and } \\
\text { reducing endotoxin and IL-10 } \\
\text { levels }\end{array}$ & 42 patients with NAFLD & [150] \\
\hline \multirow{4}{*}{$\begin{array}{c}\text { Herbal } \\
\text { medicine } \\
\text { or natural } \\
\text { active } \\
\text { ingredient }\end{array}$} & \multirow[b]{2}{*}{ Berberine } & $\begin{array}{l}\text { Preventing the development of } \\
\text { obesity and insulin resistance }\end{array}$ & HFD fed rats & [155] \\
\hline & & $\begin{array}{c}\text { Alleviating NASH and reducing } \\
\text { body weight, serum lipids levels, } \\
\text { glucose,and insulin resistance }\end{array}$ & HFD-induced NASH in rats & [158] \\
\hline & $\begin{array}{l}2,3,5,4 \text { - } \\
\text { tetrahydroxy- } \\
\text { stilbene-2-O- } \beta \text { - } \\
\text { D-glucoside } \\
\text { (TSG) }\end{array}$ & $\begin{array}{l}\text { Reversing NAFLD and reducing } \\
\text { FFA accumulation, and } \\
\text { increasing the protein expression } \\
\text { of ZO-1 and occludin }\end{array}$ & HFD-induced NAFLD in rats & [160] \\
\hline & Resveratrol & $\begin{array}{l}\text { Reducing blood glucose and } \\
\text { lipid levels, and lowering both } \\
\text { body and visceral adipose } \\
\text { weights }\end{array}$ & HFD fed mice & [162] \\
\hline
\end{tabular}




\begin{tabular}{|c|c|c|c|}
\hline \multirow[b]{2}{*}{$\begin{array}{l}\text { Qushi Huayu } \\
\text { Fang }\end{array}$} & $\begin{array}{l}\text { Reducing body weight, TG and } \\
\text { free fatty acids, alleviating } \\
\text { hepatic steatosis }\end{array}$ & HFD-induced NAFLD in rats & {$[163]$} \\
\hline & $\begin{array}{l}\text { Enhancing the hepatic anti- } \\
\text { oxidative mechanism, } \\
\text { decreasing hepatic lipid } \\
\text { synthesis, and promoting the } \\
\text { regulatory T cell inducing } \\
\text { microbiota in the gut }\end{array}$ & HFD-induced NAFLD in rats & {$[164]$} \\
\hline $\begin{array}{l}\text { Daesiho-tang } \\
\text { (DSHT) }\end{array}$ & $\begin{array}{l}\text { Ameliorating body weight gain, } \\
\text { body fat, decreasing TC and TG }\end{array}$ & HFD fed obese mice & {$[165]$} \\
\hline $\begin{array}{l}\text { Gegen Qinlian } \\
\text { Decoction } \\
\text { (GQD) }\end{array}$ & $\begin{array}{l}\text { Alleviating T2D, increasing the } \\
\text { amounts of beneficial bacteria }\end{array}$ & $\begin{array}{l}187 \text { patients with type } 2 \\
\text { diabetes (T2D) }\end{array}$ & {$[176]$} \\
\hline
\end{tabular}

\section{Conclusion and perspective}

Currently, gut microbiota has been recognized as a critical factor contributing to the development of NAFLD and the gut microbial-related mechanisms have also been well elucidated. As a result, the strategy of gut microbiota-targeted therapy on NAFLD is highly valued in the context of accumulating benefits of gut microbial modulation by using probiotics, prebiotics, synbiotics, antibiotics and herbal medicines. Although many experimental reports were exciting, discrepant results were also observed in the clinic. Therefore, the clinical efficacy of gut microbiota-targeted therapies on NAFLD still need to be confirmed with large-scale and well-organized RCT studies. The main factors contributing to the variation of therapeutic outcomes in the clinic include differences in bacterial activity of probiotics or due to the diversified dysbiosis among NAFLD patients. In this sense, probiotics with mixed bacteria such as VSL \#3 are more prospective than those with individual type of bacteria. Meanwhile, the gut microbiota-related efficacy of natural components from TCM or TCM formula itself highlighted the great potential of seeking novel medicines from TCM because some TCMs showed their effects by nourishing "good" bacteria and suppressing "bad" ones. Currently, $16 \mathrm{~S}$ rDNA-based sequencing is still the major approach for most gut microbiota-involved studies because it is relatively affordable and applicable for most laboratories. Although $16 \mathrm{~S}$ rDNA sequencing can provide general description on the structural differences of microbiome between samples, especially on the genus level, it is usually frustrating when information of specific bacteria species is heavily wanted. Consequently, metagenomics will be more applicable for figuring out specific bacterial species that may contribute to the disease development or therapeutic efficacy.

In summary, it is still in its infancy of gut microbiota-targeted therapies on NAFLD, as well as other gut microbial-related diseases. Nevertheless, we envision that more gut microbiotatargeted therapies will be trialed with the accumulating therapeutic evidence and advances in elucidation of gut microbial-related mechanisms in diseases, as well as the technological innovation of gut microbiome analysis.

\section{Acknowledgments:}

Dr. Houkai Li was funded by National Natural Science Foundation of China (No. 81673662), The Program for Professor of Special Appointment (Eastern Scholar) and Shuguang Scholar 
(16SG36) at Shanghai Institutions of Higher Learning from Shanghai Municipal Education Commission, Shanghai Pujiang Program (14PJD031) from the Science and Technology Commission of Shanghai Municipality.

Author Contributions: Junli Ma retrieved all the references and drafted the manuscript, Qihang Zhou helped in the references retrieving. Houkai Li designed the manuscript and made revision of the text.

Conflicts of Interest: The authors declare no conflict of interest.

\section{Appendix}

\section{Search strategy}

- The main source of material was pubmed, and the search keywords used were as follows : " gut microbiota”, " gut flora”, " nonalcoholic fatty liver disease(NAFLD) ” "nonalcoholic steatohepatitis(NASH)”,"steatosis", "probiotic”, "prebiotic”, "antibiotic”, "herbal medicince";

- Selected papers have no language restrictions;

- Most of the papers selected were published during the past 10 years;

- References of some identified papers were further searched for related papers to cover this topic as completely as possible.

\section{References}

1. Minemura, M.Shimizu, Y., Gut microbiota and liver diseases. World J Gastroenterol 2015, 21, 1691702; DOI: 10.3748/wjg.v21.i6.1691.

2. Yoo, J.Y.Kim, S.S., Probiotics and Prebiotics: Present Status and Future Perspectives on Metabolic Disorders. Nutrients 2016, 8, 173; DOI: 10.3390/nu8030173.

3. Hooper, L.V.;Wong, M.H.;Thelin, A.;Hansson, L.;Falk, P.G.Gordon, J.I., Molecular analysis of commensal host-microbial relationships in the intestine. Science 2001, 291, 881-4; DOI: 10.1126/science.291.5505.881.

4. de La Serre, C.B.;Ellis, C.L.;Lee, J.;Hartman, A.L.;Rutledge, J.C.Raybould, H.E., Propensity to high-fat diet-induced obesity in rats is associated with changes in the gut microbiota and gut inflammation. Am J Physiol Gastrointest Liver Physiol 2010, 299, G440-8; DOI: 10.1152/ajpgi.00098.2010.

5. Qin, J.;Li, Y.;Cai, Z.;Li, S.;Zhu, J.;Zhang, F.;Liang, S.;Zhang, W.;Guan, Y.;Shen, D.;Peng, Y.;Zhang, D.;Jie, Z.;Wu, W.;Qin, Y.;Xue, W.;Li, J.;Han, L.;Lu, D.;Wu, P.;Dai, Y.;Sun, X.;Li, Z.;Tang, A.;Zhong, S.;Li, X.;Chen, W.;Xu, R.;Wang, M.;Feng, Q.;Gong, M.;Yu, J.;Zhang, Y.;Zhang, M.;Hansen, T.;Sanchez, G.;Raes, J.;Falony, G.;Okuda, S.;Almeida, M.;LeChatelier, E.;Renault, P.;Pons, N.;Batto, J.M.;Zhang, Z.;Chen, H.;Yang, R.;Zheng, W.;Yang, H.;Wang, J.;Ehrlich, S.D.;Nielsen, R.;Pedersen, O.Kristiansen, K., A metagenome-wide association study of gut microbiota in type 2 diabetes. Nature 2012, 490, 55-60; DOI: 10.1038/nature11450.

6. Delzenne, N.M.;Cani, P.D.;Everard, A.;Neyrinck, A.M.Bindels, L.B., Gut microorganisms as promising targets for the management of type 2 diabetes. Diabetologia 2015, 58, 2206-17; DOI: 10.1007/s00125-015-3712-7.

7. Escobedo, G.;Lopez-Ortiz, E.Torres-Castro, I., Gut microbiota as a key player in triggering obesity, systemic inflammation and insulin resistance. Rev Invest Clin 2014, 66, 450-9. 
8. Mehal, W.Z., The Gordian Knot of dysbiosis, obesity and NAFLD. Nat Rev Gastroenterol Hepatol 2013, 10, 637-44; DOI: 10.1038/nrgastro.2013.146.

9. Henao-Mejia, J.;Elinav, E.;Jin, C.;Hao, L.;Mehal, W.Z.;Strowig, T.;Thaiss, C.A.;Kau, A.L.;Eisenbarth, S.C.;Jurczak, M.J.;Camporez, J.P.;Shulman, G.I.;Gordon, J.I.;Hoffman, H.M.Flavell, R.A., Inflammasome-mediated dysbiosis regulates progression of NAFLD and obesity. Nature 2012, 482, 179-85; DOI: 10.1038/nature10809.

10. DiBaise, J.K.;Zhang, H.;Crowell, M.D.;Krajmalnik-Brown, R.;Decker, G.A.Rittmann, B.E., Gut microbiota and its possible relationship with obesity. Mayo Clin Proc 2008, 83, 460-9; DOI: 10.4065/83.4.460.

11. Chong-Nguyen, C.;Duboc, H.Sokol, H., [The gut microbiota, a new cardiovascular risk factor?]. Presse Med 2017, 46, 708-713; DOI: 10.1016/j.lpm.2017.06.005.

12. Kitai, T.Tang, W.H.W., The Role and Impact of Gut Microbiota in Cardiovascular Disease. Rev Esp Cardiol (Engl Ed) 2017; DOI: 10.1016/j.rec.2017.04.007.

13. Tang, W.H.;Kitai, T.Hazen, S.L., Gut Microbiota in Cardiovascular Health and Disease. Circ Res 2017, 120, 1183-1196; DOI: 10.1161/circresaha.117.309715.

14. Wieland, A.;Frank, D.N.;Harnke, B.Bambha, K., Systematic review: microbial dysbiosis and nonalcoholic fatty liver disease. Aliment Pharmacol Ther 2015, 42, 1051-63; DOI: 10.1111/apt.13376.

15. Wree, A.;Broderick, L.;Canbay, A.;Hoffman, H.M.Feldstein, A.E., From NAFLD to NASH to cirrhosis-new insights into disease mechanisms. Nat Rev Gastroenterol Hepatol 2013, 10, 627-36; DOI: 10.1038/nrgastro.2013.149.

16. Day, C.P.James, O.F., Steatohepatitis: a tale of two "hits"? Gastroenterology 1998, 114, 842-5.

17. He, X.;Ji, G.;jia, W.Li, H., Gut Microbiota and Nonalcoholic Fatty Liver Disease: Insights on Mechanism and Application of Metabolomics. Int J Mol Sci 2016, 17, 300; DOI: 10.3390/ijms17030300.

18. Shen, J.;Obin, M.S.Zhao, L., The gut microbiota, obesity and insulin resistance. Mol Aspects Med 2013, 34, 39-58; DOI: 10.1016/j.mam.2012.11.001.

19. Mouzaki, M.Bandsma, R., Targeting the Gut Microbiota for the Treatment of Non-Alcoholic Fatty Liver Disease. Curr Drug Targets 2015, 16, 1324-31.

20. Kelishadi, R.;Farajian, S.Mirlohi, M., Probiotics as a novel treatment for non-alcoholic Fatty liver disease; a systematic review on the current evidences. Hepat Mon 2013, 13, e7233; DOI: 10.5812/hepatmon.7233.

21. Ley, R.E.;Turnbaugh, P.J.;Klein, S.Gordon, J.I., Microbial ecology: human gut microbes associated with obesity. Nature 2006, 444, 1022-3; DOI: 10.1038/4441022a.

22. Samuel, B.S.;Shaito, A.;Motoike, T.;Rey, F.E.;Backhed, F.;Manchester, J.K.;Hammer, R.E.;Williams, S.C.;Crowley, J.;Yanagisawa, M.Gordon, J.I., Effects of the gut microbiota on host adiposity are modulated by the short-chain fatty-acid binding $G$ protein-coupled receptor, Gpr41. Proc Natl Acad Sci U S A 2008, 105, 16767-72; DOI: 10.1073/pnas.0808567105.

23. Wong, J.M.;de Souza, R.;Kendall, C.W.;Emam, A.Jenkins, D.J., Colonic health: fermentation and short chain fatty acids. J Clin Gastroenterol 2006, 40, 235-43.

24. Cani, P.D.Delzenne, N.M., The role of the gut microbiota in energy metabolism and metabolic disease. Curr Pharm Des 2009, 15, 1546-58.

25. Backhed, F.;Ding, H.;Wang, T.;Hooper, L.V.;Koh, G.Y.;Nagy, A.;Semenkovich, C.F.Gordon, J.I., The gut microbiota as an environmental factor that regulates fat storage. Proc Natl Acad Sci U S A 2004, 101, 15718-23; DOI: 10.1073/pnas.0407076101. 
26. Turnbaugh, P.J.;Ley, R.E.;Mahowald, M.A.;Magrini, V.;Mardis, E.R.Gordon, J.I., An obesityassociated gut microbiome with increased capacity for energy harvest. Nature 2006, 444, 1027-31; DOI: $10.1038 /$ nature05414.

27. Moschen, A.R.;Kaser, S.Tilg, H., Non-alcoholic steatohepatitis: a microbiota-driven disease. Trends Endocrinol Metab 2013, 24, 537-45; DOI: 10.1016/j.tem.2013.05.009.

28. Pagano, G.;Pacini, G.;Musso, G.;Gambino, R.;Mecca, F.;Depetris, N.;Cassader, M.;David, E.;Cavallo-Perin, P.Rizzetto, M., Nonalcoholic steatohepatitis, insulin resistance, and metabolic syndrome: further evidence for an etiologic association. Hepatology 2002, 35, 367-72; DOI: 10.1053/jhep.2002.30690.

29. Tarantino, G.Caputi, A., JNKs, insulin resistance and inflammation: A possible link between NAFLD and coronary artery disease. World J Gastroenterol 2011, 17, 3785-94; DOI: 10.3748/wjg.v17.i33.3785.

30. Farrell, G.C., Signalling links in the liver: knitting SOCS with fat and inflammation. J Hepatol 2005, 43, 193-6; DOI: 10.1016/j.jhep.2005.04.004.

31. Cani, P.D.;Amar, J.;Iglesias, M.A.;Poggi, M.;Knauf, C.;Bastelica, D.;Neyrinck, A.M.;Fava, F.;Tuohy, K.M.;Chabo, C.;Waget, A.;Delmee, E.;Cousin, B.;Sulpice, T.;Chamontin, B.;Ferrieres, J.;Tanti, J.F.;Gibson, G.R.;Casteilla, L.;Delzenne, N.M.;Alessi, M.C.Burcelin, R., Metabolic endotoxemia initiates obesity and insulin resistance. Diabetes 2007, 56, 1761-72; DOI: 10.2337/db06-1491.

32. Caesar, R.;Reigstad, C.S.;Backhed, H.K.;Reinhardt, C.;Ketonen, M.;Lunden, G.O.;Cani, P.D.Backhed, F., Gut-derived lipopolysaccharide augments adipose macrophage accumulation but is not essential for impaired glucose or insulin tolerance in mice. Gut 2012, 61, 1701-7; DOI: 10.1136/gutjnl-2011-301689.

33. Wellen, K.E.Hotamisligil, G.S., Inflammation, stress, and diabetes. J Clin Invest 2005, 115, 1111-9; DOI: $10.1172 /$ jci25102.

34. Cani, P.D.Delzenne, N.M., Gut microflora as a target for energy and metabolic homeostasis. Curr Opin Clin Nutr Metab Care 2007, 10, 729-34; DOI: 10.1097/MCO.0b013e3282efdebb.

35. Corbin, K.D.Zeisel, S.H., Choline metabolism provides novel insights into nonalcoholic fatty liver disease and its progression. Curr Opin Gastroenterol 2012, 28, 159-65; DOI: 10.1097/MOG.0b013e32834e7b4b.

36. Zeisel, S.H., Choline: critical role during fetal development and dietary requirements in adults. Annu Rev Nutr 2006, 26, 229-50; DOI: 10.1146/annurev.nutr.26.061505.111156.

37. Wang, Z.;Klipfell, E.;Bennett, B.J.;Koeth, R.;Levison, B.S.;Dugar, B.;Feldstein, A.E.;Britt, E.B.;Fu, X.;Chung, Y.M.;Wu, Y.;Schauer, P.;Smith, J.D.;Allayee, H.;Tang, W.H.;DiDonato, J.A.;Lusis, A.J.Hazen, S.L., Gut flora metabolism of phosphatidylcholine promotes cardiovascular disease. Nature 2011, 472, 57-63; DOI: 10.1038/nature09922.

38. Brown, J.M.Hazen, S.L., The gut microbial endocrine organ: bacterially derived signals driving cardiometabolic diseases. Annu Rev Med 2015, 66, 343-59; DOI: 10.1146/annurev-med-060513093205.

39. Tang, W.H.;Wang, Z.;Levison, B.S.;Koeth, R.A.;Britt, E.B.;Fu, X.;Wu, Y.Hazen, S.L., Intestinal microbial metabolism of phosphatidylcholine and cardiovascular risk. N Engl J Med 2013, 368, 1575-84; DOI: 10.1056/NEJMoa1109400. 
40. Spencer, M.D.;Hamp, T.J.;Reid, R.W.;Fischer, L.M.;Zeisel, S.H.Fodor, A.A., Association between composition of the human gastrointestinal microbiome and development of fatty liver with choline deficiency. Gastroenterology 2011, 140, 976-86; DOI: 10.1053/j.gastro.2010.11.049.

41. Lorenzo-Zuniga, V.;Bartoli, R.;Planas, R.;Hofmann, A.F.;Vinado, B.;Hagey, L.R.;Hernandez, J.M.;Mane, J.;Alvarez, M.A.;Ausina, V.Gassull, M.A., Oral bile acids reduce bacterial overgrowth, bacterial translocation, and endotoxemia in cirrhotic rats. Hepatology 2003, 37, 551-7; DOI: 10.1053/jhep.2003.50116.

42. Ogata, Y.;Nishi, M.;Nakayama, H.;Kuwahara, T.;Ohnishi, Y.Tashiro, S., Role of bile in intestinal barrier function and its inhibitory effect on bacterial translocation in obstructive jaundice in rats. J Surg Res 2003, 115, 18-23.

43. Fuchs, C.;Claudel, T.Trauner, M., Bile acid-mediated control of liver triglycerides. Semin Liver Dis 2013, 33, 330-42; DOI: 10.1055/s-0033-1358520.

44. Houten, S.M.;Watanabe, M.Auwerx, J., Endocrine functions of bile acids. EMBO J 2006, 25, 141925; DOI: 10.1038/sj.emboj.7601049.

45. Hylemon, P.B.;Zhou, H.;Pandak, W.M.;Ren, S.;Gil, G.Dent, P., Bile acids as regulatory molecules. J Lipid Res 2009, 50, 1509-20; DOI: 10.1194/jlr.R900007-JLR200.

46. Claudel, T.;Staels, B.Kuipers, F., The Farnesoid X receptor: a molecular link between bile acid and lipid and glucose metabolism. Arterioscler Thromb Vasc Biol 2005, 25, 2020-30; DOI: 10.1161/01.ATV.0000178994.21828.a7.

47. Jiang, C.;Xie, C.;Li, F.;Zhang, L.;Nichols, R.G.;Krausz, K.W.;Cai, J.;Qi, Y.;Fang, Z.Z.;Takahashi, S.;Tanaka, N.;Desai, D.;Amin, S.G.;Albert, I.;Patterson, A.D.Gonzalez, F.J., Intestinal farnesoid X receptor signaling promotes nonalcoholic fatty liver disease. J Clin Invest 2015, 125, 386-402; DOI: 10.1172/jci76738.

48. Bashiardes, S.;Shapiro, H.;Rozin, S.;Shibolet, O.Elinav, E., Non-alcoholic fatty liver and the gut microbiota. Mol Metab 2016, 5, 782-94; DOI: 10.1016/j.molmet.2016.06.003.

49. Abu-Shanab, A.Quigley, E.M., The role of the gut microbiota in nonalcoholic fatty liver disease. Nat Rev Gastroenterol Hepatol 2010, 7, 691-701; DOI: 10.1038/nrgastro.2010.172.

50. Kobyliak, N.;Virchenko, O.Falalyeyeva, T., Pathophysiological role of host microbiota in the development of obesity. Nutr J 2016, 15, 43; DOI: 10.1186/s12937-016-0166-9.

51. Paolella, G.;Mandato, C.;Pierri, L.;Poeta, M.;Di Stasi, M.Vajro, P., Gut-liver axis and probiotics: their role in non-alcoholic fatty liver disease. World J Gastroenterol 2014, 20, 15518-31; DOI: 10.3748/wjg.v20.i42.15518.

52. Marchesi, J.R.;Adams, D.H.;Fava, F.;Hermes, G.D.;Hirschfield, G.M.;Hold, G.;Quraishi, M.N.;Kinross, J.;Smidt, H.;Tuohy, K.M.;Thomas, L.V.;Zoetendal, E.G.Hart, A., The gut microbiota and host health: a new clinical frontier. Gut 2016, 65, 330-9; DOI: 10.1136/gutjnl-2015309990.

53. Kirpich, I.A.;Marsano, L.S.McClain, C.J., Gut-liver axis, nutrition, and non-alcoholic fatty liver disease. Clin Biochem 2015, 48, 923-30; DOI: 10.1016/j.clinbiochem.2015.06.023.

54. Usami, M.;Miyoshi, M.Yamashita, H., Gut microbiota and host metabolism in liver cirrhosis. World J Gastroenterol 2015, 21, 11597-608; DOI: 10.3748/wjg.v21.i41.11597.

55. Festi, D.;Schiumerini, R.;Eusebi, L.H.;Marasco, G.;Taddia, M.Colecchia, A., Gut microbiota and metabolic syndrome. World J Gastroenterol 2014, 20, 16079-94; DOI: 10.3748/wjg.v20.i43.16079. 
56. Druart, C.;Alligier, M.;Salazar, N.;Neyrinck, A.M.Delzenne, N.M., Modulation of the gut microbiota by nutrients with prebiotic and probiotic properties. Adv Nutr 2014, 5, 624S-633S; DOI: 10.3945/an.114.005835.

57. Finelli, C.Tarantino, G., Non-alcoholic fatty liver disease, diet and gut microbiota. EXCLI J 2014, 13, 461-90.

58. Patel, R.DuPont, H.L., New approaches for bacteriotherapy: prebiotics, new-generation probiotics, and synbiotics. Clin Infect Dis 2015, 60 Suppl 2, S108-21; DOI: 10.1093/cid/civ177.

59. Ferolla, S.M.;Armiliato, G.N.;Couto, C.A.Ferrari, T.C., The role of intestinal bacteria overgrowth in obesity-related nonalcoholic fatty liver disease. Nutrients 2014, 6, 5583-99; DOI: 10.3390/nu6125583.

60. Fialho, A.;Thota, P.;McCullough, A.J.Shen, B., Small Intestinal Bacterial Overgrowth Is Associated with Non-Alcoholic Fatty Liver Disease. J Gastrointestin Liver Dis 2016, 25, 159-65; DOI: 10.15403/jgld.2014.1121.252.iwg.

61. Duvnjak, M.;Tomasic, V.;Gomercic, M.;Smircic Duvnjak, L.;Barsic, N.Lerotic, I., Therapy of nonalcoholic fatty liver disease: current status. J Physiol Pharmacol 2009, 60 Suppl 7, 57-66.

62. Sanders, M.E., Probiotics: definition, sources, selection, and uses. Clin Infect Dis 2008, 46 Suppl 2, S58-61; discussion S144-51; DOI: 10.1086/523341.

63. Miura, K.Ohnishi, H., Role of gut microbiota and Toll-like receptors in nonalcoholic fatty liver disease. World J Gastroenterol 2014, 20, 7381-91; DOI: 10.3748/wjg.v20.i23.7381.

64. Okubo, H.;Sakoda, H.;Kushiyama, A.;Fujishiro, M.;Nakatsu, Y.;Fukushima, T.;Matsunaga, Y.;Kamata, H.;Asahara, T.;Yoshida, Y.;Chonan, O.;Iwashita, M.;Nishimura, F.Asano, T., Lactobacillus casei strain Shirota protects against nonalcoholic steatohepatitis development in a rodent model. Am J Physiol Gastrointest Liver Physiol 2013, 305, G911-8; DOI: 10.1152/ajpgi.00225.2013.

65. Naito, E.;Yoshida, Y.;Makino, K.;Kounoshi, Y.;Kunihiro, S.;Takahashi, R.;Matsuzaki, T.;Miyazaki, K.Ishikawa, F., Beneficial effect of oral administration of Lactobacillus casei strain Shirota on insulin resistance in diet-induced obesity mice. J Appl Microbiol 2011, 110, 650-7; DOI: 10.1111/j.1365-2672.2010.04922.x.

66. Wagnerberger, S.;Spruss, A.;Kanuri, G.;Stahl, C.;Schroder, M.;Vetter, W.;Bischoff, S.C.Bergheim, I., Lactobacillus casei Shirota protects from fructose-induced liver steatosis: a mouse model. J Nutr Biochem 2013, 24, 531-8; DOI: 10.1016/j.jnutbio.2012.01.014.

67. Fukushima, M.;Yamada, A.;Endo, T.Nakano, M., Effects of a mixture of organisms, Lactobacillus acidophilus or Streptococcus faecalis on delta6-desaturase activity in the livers of rats fed a fatand cholesterol-enriched diet. Nutrition 1999, 15, 373-8.

68. Nguyen, T.D.;Kang, J.H.Lee, M.S., Characterization of Lactobacillus plantarum PH04, a potential probiotic bacterium with cholesterol-lowering effects. Int J Food Microbiol 2007, 113, 358-61; DOI: 10.1016/j.ijfoodmicro.2006.08.015.

69. Anderson, J.W.Gilliland, S.E., Effect of fermented milk (yogurt) containing Lactobacillus acidophilus L1 on serum cholesterol in hypercholesterolemic humans. J Am Coll Nutr 1999, 18, 43-50.

70. Sohn, W.;Jun, D.W.;Lee, K.N.;Lee, H.L.;Lee, O.Y.;Choi, H.S.Yoon, B.C., Lactobacillus paracasei Induces M2-Dominant Kupffer Cell Polarization in a Mouse Model of Nonalcoholic Steatohepatitis. Dig Dis Sci 2015, 60, 3340-50; DOI: 10.1007/s10620-015-3770-1. 
71. Ford, A.C.;Quigley, E.M.;Lacy, B.E.;Lembo, A.J.;Saito, Y.A.;Schiller, L.R.;Soffer, E.E.;Spiegel, B.M.Moayyedi, P., Efficacy of prebiotics, probiotics, and synbiotics in irritable bowel syndrome and chronic idiopathic constipation: systematic review and meta-analysis. Am J Gastroenterol 2014, 109, 1547-61; quiz 1546, 1562; DOI: 10.1038/ajg.2014.202.

72. Ghouri, Y.A.;Richards, D.M.;Rahimi, E.F.;Krill, J.T.;Jelinek, K.A.DuPont, A.W., Systematic review of randomized controlled trials of probiotics, prebiotics, and synbiotics in inflammatory bowel disease. Clin Exp Gastroenterol 2014, 7, 473-87; DOI: 10.2147/ceg.s27530.

73. Fazeli, H.;Moshtaghian, J.;Mirlohi, M.Shirzadi, M., Reduction in serum lipid parameters by incorporation of a native strain of Lactobacillus Plantarum A7 in Mice. Iranian Journal of Diabetes $\mathcal{E}$ Lipid Disorders 2010, 9, 1-7.

74. Wang, Y.;Xu, N.;Xi, A.;Ahmed, Z.;Zhang, B.Bai, X., Effects of Lactobacillus plantarum MA2 isolated from Tibet kefir on lipid metabolism and intestinal microflora of rats fed on highcholesterol diet. Appl Microbiol Biotechnol 2009, 84, 341-7; DOI: 10.1007/s00253-009-2012-x.

75. Li, C.;Nie, S.P.;Zhu, K.X.;Ding, Q.;Xiong, T.Xie, M.Y., Lactobacillus plantarum NCU116 improves liver function, oxidative stress and lipid metabolism in rats with high fat diet induced non-alcoholic fatty liver disease. Food Funct 2014, 5, 3216-23; DOI: 10.1039/c4fo00549j.

76. Ritze, Y.;Bardos, G.;Claus, A.;Ehrmann, V.;Bergheim, I.;Schwiertz, A.Bischoff, S.C., Lactobacillus rhamnosus GG protects against non-alcoholic fatty liver disease in mice. PLoS One 2014, 9, e80169; DOI: 10.1371/journal.pone.0080169.

77. Kim, B.;Park, K.Y.jJi, Y.;Park, S.;Holzapfel, W.Hyun, C.K., Protective effects of Lactobacillus rhamnosus GG against dyslipidemia in high-fat diet-induced obese mice. Biochem Biophys Res Commun 2016, 473, 530-6; DOI: 10.1016/j.bbrc.2016.03.107.

78. Xin, J.;Zeng, D.;Wang, H.;Ni, X.;Yi, D.;Pan, K.Jing, B., Preventing non-alcoholic fatty liver disease through Lactobacillus johnsonii BS15 by attenuating inflammation and mitochondrial injury and improving gut environment in obese mice. Appl Microbiol Biotechnol 2014, 98, 6817-29; DOI: 10.1007/s00253-014-5752-1.

79. Hsieh, F.C.;Lee, C.L.;Chai, C.Y.;Chen, W.T.;Lu, Y.C.Wu, C.S., Oral administration of Lactobacillus reuteri GMNL-263 improves insulin resistance and ameliorates hepatic steatosis in high fructose-fed rats. Nutr Metab (Lond) 2013, 10, 35; DOI: 10.1186/1743-7075-10-35.

80. Kang, J.H.;Yun, S.I.;Park, M.H.;Park, J.H.;Jeong, S.Y.Park, H.O., Anti-obesity effect of Lactobacillus gasseri BNR17 in high-sucrose diet-induced obese mice. PLoS One 2013, 8, e54617; DOI: 10.1371/journal.pone.0054617.

81. Aoki, R.;Kamikado, K.;Suda, W.;Takii, H.;Mikami, Y.;Suganuma, N.;Hattori, M.Koga, Y., A proliferative probiotic Bifidobacterium strain in the gut ameliorates progression of metabolic disorders via microbiota modulation and acetate elevation. Sci Rep 2017, 7, 43522; DOI: 10.1038/srep43522.

82. Ren, T.;Huang, C.Cheng, M., Dietary blueberry and bifidobacteria attenuate nonalcoholic fatty liver disease in rats by affecting SIRT1-mediated signaling pathway. Oxid Med Cell Longev 2014, 2014, 469059; DOI: 10.1155/2014/469059.

83. Plaza-Diaz, J.;Ruiz-Ojeda, F.J.;Vilchez-Padial, L.M.Gil, A., Evidence of the Anti-Inflammatory Effects of Probiotics and Synbiotics in Intestinal Chronic Diseases. Nutrients 2017, 9; DOI: 10.3390/nu9060555. 
84. Chen, J.;Wang, R.;Li, X.F.Wang, R.L., Bifidobacterium adolescentis supplementation ameliorates visceral fat accumulation and insulin sensitivity in an experimental model of the metabolic syndrome. Br J Nutr 2012, 107, 1429-34; DOI: 10.1017/S0007114511004491.

85. Cano, P.G.;Santacruz, A.;Trejo, F.M.Sanz, Y., Bifidobacterium CECT 7765 improves metabolic and immunological alterations associated with obesity in high-fat diet-fed mice. Obesity (Silver Spring) 2013, 21, 2310-21; DOI: 10.1002/oby.20330.

86. Xu, R.Y.;Wan, Y.P.;Fang, Q.Y.;Lu, W.Cai, W., Supplementation with probiotics modifies gut flora and attenuates liver fat accumulation in rat nonalcoholic fatty liver disease model. J Clin Biochem Nutr 2012, 50, 72-7; DOI: 10.3164/jcbn.11-38.

87. Sinha, A.;Gupta, S.S.;Chellani, H.;Maliye, C.;Kumari, V.;Arya, S.;Garg, B.S.;Gaur, S.D.;Gaind, R.;Deotale, V.;Taywade, M.;Prasad, M.S.;Thavraj, V.;Mukherjee, A.Roy, M., Role of probiotics VSL\#3 in prevention of suspected sepsis in low birthweight infants in India: a randomised controlled trial. BMJ Open 2015, 5, e006564; DOI: 10.1136/bmjopen-2014-006564.

88. Fedorak, R.N.;Feagan, B.G.;Hotte, N.;Leddin, D.;Dieleman, L.A.;Petrunia, D.M.;Enns, R.;Bitton, A.;Chiba, N.;Pare, P.;Rostom, A.;Marshall, J.;Depew, W.;Bernstein, C.N.;Panaccione, R.;Aumais, G.;Steinhart, A.H.;Cockeram, A.;Bailey, R.J.;Gionchetti, P.;Wong, C.Madsen, K., The probiotic VSL\#3 has anti-inflammatory effects and could reduce endoscopic recurrence after surgery for Crohn's disease. Clin Gastroenterol Hepatol 2015, 13, 928-35 e2; DOI: 10.1016/j.cgh.2014.10.031.

89. Dhiman, R.K.;Rana, B.;Agrawal, S.;Garg, A.;Chopra, M.;Thumburu, K.K.;Khattri, A.;Malhotra, S.;Duseja, A.Chawla, Y.K., Probiotic VSL\#3 reduces liver disease severity and hospitalization in patients with cirrhosis: a randomized, controlled trial. Gastroenterology 2014, 147, 1327-37 e3; DOI: 10.1053/j.gastro.2014.08.031.

90. Wong, R.K.;Yang, C.;Song, G.H.;Wong, J.Ho, K.Y., Melatonin regulation as a possible mechanism for probiotic (VSL\#3) in irritable bowel syndrome: a randomized double-blinded placebo study. Dig Dis Sci 2015, 60, 186-94; DOI: 10.1007/s10620-014-3299-8.

91. Mencarelli, A.;Cipriani, S.;Renga, B.;Bruno, A.;D'Amore, C.;Distrutti, E.Fiorucci, S., VSL\#3 resets insulin signaling and protects against $\mathrm{NASH}$ and atherosclerosis in a model of genetic dyslipidemia and intestinal inflammation. PLoS One 2012, 7, e45425; DOI: 10.1371/journal.pone.0045425.

92. Esposito, E.;Iacono, A.;Bianco, G.;Autore, G.;Cuzzocrea, S.;Vajro, P.;Canani, R.B.;Calignano, A.;Raso, G.M.Meli, R., Probiotics reduce the inflammatory response induced by a high-fat diet in the liver of young rats. J Nutr 2009, 139, 905-11; DOI: 10.3945/jn.108.101808.

93. Li, Z.;Yang, S.;Lin, H.;Huang, J.;Watkins, P.A.;Moser, A.B.;Desimone, C.;Song, X.Y.Diehl, A.M., Probiotics and antibodies to TNF inhibit inflammatory activity and improve nonalcoholic fatty liver disease. Hepatology 2003, 37, 343-50; DOI: 10.1053/jhep.2003.50048.

94. Ma, X.;Hua, J.Li, Z., Probiotics improve high fat diet-induced hepatic steatosis and insulin resistance by increasing hepatic NKT cells. J Hepatol 2008, 49, 821-30; DOI: 10.1016/j.jhep.2008.05.025.

95. Velayudham, A.;Dolganiuc, A.;Ellis, M.;Petrasek, J.;Kodys, K.;Mandrekar, P.Szabo, G., VSL\#3 probiotic treatment attenuates fibrosis without changes in steatohepatitis in a diet-induced nonalcoholic steatohepatitis model in mice. Hepatology 2009, 49, 989-97; DOI: 10.1002/hep.22711.

96. Mei, L.;Tang, Y.;Li, M.;Yang, P.;Liu, Z.;Yuan, J.Zheng, P., Co-Administration of CholesterolLowering Probiotics and Anthraquinone from Cassia obtusifolia L. Ameliorate Non-Alcoholic Fatty Liver. PLoS One 2015, 10, e0138078; DOI: 10.1371/journal.pone.0138078. 
97. Xue, L.;He, J.;Gao, N.;Lu, X.;Li, M.;Wu, X.;Liu, Z.;jin, Y.;Liu, J.;Xu, J.Geng, Y., Probiotics may delay the progression of nonalcoholic fatty liver disease by restoring the gut microbiota structure and improving intestinal endotoxemia. Sci Rep 2017, 7, 45176; DOI: 10.1038/srep45176.

98. Kim, D.H.;Kim, H.;Jeong, D.;Kang, I.B.;Chon, J.W.;Kim, H.S.;Song, K.Y.Seo, K.H., Kefir alleviates obesity and hepatic steatosis in high-fat diet-fed mice by modulation of gut microbiota and mycobiota: targeted and untargeted community analysis with correlation of biomarkers. J Nutr Biochem 2017, 44, 35-43; DOI: 10.1016/j.jnutbio.2017.02.014.

99. Karahan, N.;Isler, M.;Koyu, A.;Karahan, A.G.;Basyigit Kilic, G.;Ciris, I.M.;Sutcu, R.;Onaran, I.;Cam, H.Keskin, M., Effects of probiotics on methionine choline deficient diet-induced steatohepatitis in rats. Turk J Gastroenterol 2012, 23, 110-21.

100. Ji, Y.S.;Kim, H.N.;Park, H.J.;Lee, J.E.;Yeo, S.Y.;Yang, J.S.;Park, S.Y.;Yoon, H.S.;Cho, G.S.;Franz, C.M.;Bomba, A.;Shin, H.K.Holzapfel, W.H., Modulation of the murine microbiome with a concomitant anti-obesity effect by Lactobacillus rhamnosus GG and Lactobacillus sakei NR28. Benef Microbes 2012, 3, 13-22; DOI: 10.3920/bm2011.0046.

101. Kobyliak, N.;Falalyeyeva, T.;Bodnar, P.Beregova, T., Probiotics Supplemented with Omega-3 Fatty Acids are More Effective for Hepatic Steatosis Reduction in an Animal Model of Obesity. Probiotics \& Antimicrobial Proteins 2016, 1-8.

102. Seo, M.;Inoue, I.;Tanaka, M.;Matsuda, N.;Nakano, T.;Awata, T.;Katayama, S.;Alpers, D.H.Komoda, T., Clostridium butyricum MIYAIRI 588 improves high-fat diet-induced nonalcoholic fatty liver disease in rats. Dig Dis Sci 2013, 58, 3534-44; DOI: 10.1007/s10620-013-2879-3.

103. Endo, H.;Niioka, M.;Kobayashi, N.;Tanaka, M.Watanabe, T., Butyrate-producing probiotics reduce nonalcoholic fatty liver disease progression in rats: new insight into the probiotics for the gut-liver axis. PLoS One 2013, 8, e63388; DOI: 10.1371/journal.pone.0063388.

104. Alisi, A.;Bedogni, G.;Baviera, G.;Giorgio, V.;Porro, E.;Paris, C.;Giammaria, P.;Reali, L.;Anania, F.Nobili, V., Randomised clinical trial: The beneficial effects of VSL\#3 in obese children with nonalcoholic steatohepatitis. Aliment Pharmacol Ther 2014, 39, 1276-85; DOI: 10.1111/apt.12758.

105. Vajro, P.;Mandato, C.;Licenziati, M.R.;Franzese, A.;Vitale, D.F.;Lenta, S.;Caropreso, M.;Vallone, G.Meli, R., Effects of Lactobacillus rhamnosus strain GG in pediatric obesity-related liver disease. J Pediatr Gastroenterol Nutr 2011, 52, 740-3; DOI: 10.1097/MPG.0b013e31821f9b85.

106. Aller, R.;De Luis, D.A.;Izaola, O.;Conde, R.;Gonzalez Sagrado, M.;Primo, D.;De La Fuente, B.Gonzalez, J., Effect of a probiotic on liver aminotransferases in nonalcoholic fatty liver disease patients: a double blind randomized clinical trial. Eur Rev Med Pharmacol Sci 2011, 15, 1090-5.

107. Sepideh, A.;Karim, P.;Hossein, A.;Leila, R.;Hamdollah, M.;Mohammad E, G.;Mojtaba, S.;Mohammad, S.;Ghader, G.Seyed Moayed, A., Effects of Multistrain Probiotic Supplementation on Glycemic and Inflammatory Indices in Patients with Nonalcoholic Fatty Liver Disease: A Double-Blind Randomized Clinical Trial. Journal of the American College of Nutrition 2016, 35, 500-505; DOI: 10.1080/07315724.2015.1031355.

108. Shavakhi, A.;Minakari, M.;Firouzian, H.;Assali, R.;Hekmatdoost, A.Ferns, G., Effect of a Probiotic and Metformin on Liver Aminotransferases in Non-alcoholic Steatohepatitis: A Double Blind Randomized Clinical Trial. Int J Prev Med 2013, 4, 531-7.

109. Zvenigorodskaia, L.A.;Cherkashova, E.A.;Samsonova, N.G.;Nilova, T.V.Sil'verstova, S., [Advisability of using probiotics in the treatment of atherogenic dyslipidemia]. Eksp Klin Gastroenterol 2011, 37-43. 
110. Solga, S.F.;Buckley, G.;Clark, J.M.;Horska, A.Diehl, A.M., The effect of a probiotic on hepatic steatosis. J Clin Gastroenterol 2008, 42, 1117-9; DOI: 10.1097/MCG.0b013e31816d920c.

111. Andreasen, A.S.;Larsen, N.;Pedersen-Skovsgaard, T.;Berg, R.M.;Moller, K.;Svendsen, K.D.;Jakobsen, M.Pedersen, B.K., Effects of Lactobacillus acidophilus NCFM on insulin sensitivity and the systemic inflammatory response in human subjects. Br J Nutr 2010, 104, 18318; DOI: $10.1017 / \mathrm{s} 0007114510002874$.

112. Mahboobi, S.;Iraj, B.;Maghsoudi, Z.;Feizi, A.;Ghiasvand, R.;Askari, G.Maayeshi, N., The effects of probiotic supplementation on markers of blood lipids, and blood pressure in patients with prediabetes: a randomized clinical trial. Int J Prev Med 2014, 5, 1239-46.

113. Lewis, S.J.Burmeister, S., A double-blind placebo-controlled study of the effects of Lactobacillus acidophilus on plasma lipids. Eur J Clin Nutr 2005, 59, 776-80; DOI: 10.1038/sj.ejcn.1602139.

114. Gibson, G.R.Roberfroid, M.B., Dietary modulation of the human colonic microbiota: introducing the concept of prebiotics. J Nutr 1995, 125, 1401-12.

115. Roberfroid, M., Prebiotics: the concept revisited. J Nutr 2007, 137, 830S-7S.

116. Roberfroid, M.B., Inulin-type fructans: functional food ingredients. J Nutr 2007, 137, 2493S-2502S.

117. Parnell, J.A.;Raman, M.;Rioux, K.P.Reimer, R.A., The potential role of prebiotic fibre for treatment and management of non-alcoholic fatty liver disease and associated obesity and insulin resistance. Liver Int 2012, 32, 701-11; DOI: 10.1111/j.1478-3231.2011.02730.x.

118. Daubioul, C.A.;Horsmans, Y.;Lambert, P.;Danse, E.Delzenne, N.M., Effects of oligofructose on glucose and lipid metabolism in patients with nonalcoholic steatohepatitis: results of a pilot study. Eur J Clin Nutr 2005, 59, 723-6; DOI: 10.1038/sj.ejcn.1602127.

119. Cani, P.D.;Possemiers, S.;Van de Wiele, T.;Guiot, Y.;Everard, A.;Rottier, O.;Geurts, L.;Naslain, D.;Neyrinck, A.;Lambert, D.M.;Muccioli, G.G.Delzenne, N.M., Changes in gut microbiota control inflammation in obese mice through a mechanism involving GLP-2-driven improvement of gut permeability. Gut 2009, 58, 1091-103; DOI: 10.1136/gut.2008.165886.

120. Matsumoto, K.;Ichimura, M.;Tsuneyama, K.;Moritoki, Y.;Tsunashima, H.;Omagari, K.;Hara, M.;Yasuda, I.;Miyakawa, H.Kikuchi, K., Fructo-oligosaccharides and intestinal barrier function in a methionine-choline-deficient mouse model of nonalcoholic steatohepatitis. PLoS One 2017, 12, e0175406; DOI: 10.1371/journal.pone.0175406.

121. Pachikian, B.D.;Essaghir, A.;Demoulin, J.B.;Catry, E.;Neyrinck, A.M.;Dewulf, E.M.;Sohet, F.M.;Portois， L.;Clerbaux， L.A.;Carpentier， Y.A.;Possemiers， S.;Bommer， G.T.;Cani, P.D.Delzenne, N.M., Prebiotic approach alleviates hepatic steatosis: implication of fatty acid oxidative and cholesterol synthesis pathways. Mol Nutr Food Res 2013, 57, 347-59; DOI: 10.1002/mnfr.201200364.

122. Lau, E.;Carvalho, D.Freitas, P., Gut Microbiota: Association with NAFLD and Metabolic Disturbances. Biomed Res Int 2015, 2015, 979515; DOI: 10.1155/2015/979515.

123. Salminen, S.Salminen, E., Lactulose, lactic acid bacteria, intestinal microecology and mucosal protection. Scand J Gastroenterol Suppl 1997, 222, 45-8; DOI: 10.1080/00365521.1997.11720717.

124. Fan, J.G.;Xu, Z.J.Wang, G.L., Effect of lactulose on establishment of a rat non-alcoholic steatohepatitis model. World J Gastroenterol 2005, 11, 5053-6.

125. Neyrinck, A.M.;Possemiers, S.;Verstraete, W.;De Backer, F.;Cani, P.D.Delzenne, N.M., Dietary modulation of clostridial cluster XIVa gut bacteria (Roseburia spp.) by chitin-glucan fiber improves host metabolic alterations induced by high-fat diet in mice. J Nutr Biochem 2012, 23, 519; DOI: 10.1016/j.jnutbio.2010.10.008. 
126. Singh, D.P.;Khare, P.;Zhu, J.;Kondepudi, K.K.;Singh, J.;Baboota, R.K.;Boparai, R.K.;Khardori, R.;Chopra, K.Bishnoi, M., A novel cobiotic-based preventive approach against high-fat dietinduced adiposity, nonalcoholic fatty liver and gut derangement in mice. Int J Obes (Lond) 2016, 40, 487-96; DOI: 10.1038/ijo.2015.197.

127. Micka, A.;Siepelmeyer, A.;Holz, A.;Theis, S.Schon, C., Effect of consumption of chicory inulin on bowel function in healthy subjects with constipation: a randomized, double-blind, placebocontrolled trial. Int J Food Sci Nutr 2017, 68, 82-89; DOI: 10.1080/09637486.2016.1212819.

128. Poesen, R.;Evenepoel, P.;de Loor, H.;Delcour, J.A.;Courtin, C.M.;Kuypers, D.;Augustijns, P.;Verbeke, K.Meijers, B., The Influence of Prebiotic Arabinoxylan Oligosaccharides on Microbiota Derived Uremic Retention Solutes in Patients with Chronic Kidney Disease: A Randomized Controlled Trial. PLoS One 2016, 11, e0153893; DOI: 10.1371/journal.pone.0153893.

129. Lambert, J.E.;Parnell, J.A.;Eksteen, B.;Raman, M.;Bomhof, M.R.;Rioux, K.P.;Madsen, K.L.Reimer, R.A., Gut microbiota manipulation with prebiotics in patients with non-alcoholic fatty liver disease: a randomized controlled trial protocol. BMC Gastroenterol 2015, 15, 169; DOI: 10.1186/s12876-015-0400-5.

130. Mitchell, C.M.;Davy, B.M.;Halliday, T.M.;Hulver, M.W.;Neilson, A.P.;Ponder, M.A.Davy, K.P., The effect of prebiotic supplementation with inulin on cardiometabolic health: Rationale, design, and methods of a controlled feeding efficacy trial in adults at risk of type 2 diabetes. Contemp Clin Trials 2015, 45, 328-337; DOI: 10.1016/j.cct.2015.10.012.

131. Savaiano, D.A.;Ritter, A.J.;Klaenhammer, T.R.;James, G.M.;Longcore, A.T.;Chandler, J.R.;Walker, W.A.Foyt, H.L., Improving lactose digestion and symptoms of lactose intolerance with a novel galacto-oligosaccharide (RP-G28): a randomized, double-blind clinical trial. Nutr J 2013, 12, 160; DOI: 10.1186/1475-2891-12-160.

132. Holscher, H.D.;Faust, K.L.;Czerkies, L.A.;Litov, R.;Ziegler, E.E.;Lessin, H.;Hatch, T.;Sun, S.Tappenden, K.A., Effects of prebiotic-containing infant formula on gastrointestinal tolerance and fecal microbiota in a randomized controlled trial. JPEN J Parenter Enteral Nutr 2012, 36, 95S105S; DOI: 10.1177/0148607111430087.

133. Dewulf, E.M.;Cani, P.D.;Claus, S.P.;Fuentes, S.;Puylaert, P.G.;Neyrinck, A.M.;Bindels, L.B.;de Vos, W.M.;Gibson, G.R.;Thissen, J.P.Delzenne, N.M., Insight into the prebiotic concept: lessons from an exploratory, double blind intervention study with inulin-type fructans in obese women. Gut 2013, 62, 1112-21; DOI: 10.1136/gutjnl-2012-303304.

134. Cani, P.D.Delzenne, N.M., The gut microbiome as therapeutic target. Pharmacol Ther 2011, 130, 202-12; DOI: 10.1016/j.pharmthera.2011.01.012.

135. de Vrese, M.Schrezenmeir, J., Probiotics, prebiotics, and synbiotics. Adv Biochem Eng Biotechnol 2008, 111, 1-66; DOI: 10.1007/10_2008_097.

136. Pandey, K.R.;Naik, S.R.Vakil, B.V., Probiotics, prebiotics and synbiotics- a review. J Food Sci Technol 2015, 52, 7577-87; DOI: 10.1007/s13197-015-1921-1.

137. Raso, G.M.;Simeoli, R.;Iacono, A.;Santoro, A.;Amero, P.;Paciello, O.;Russo, R.;D'Agostino, G.;Di Costanzo, M.;Canani, R.B.;Calignano, A.Meli, R., Effects of a Lactobacillus paracasei B21060 based synbiotic on steatosis, insulin signaling and toll-like receptor expression in rats fed a highfat diet. J Nutr Biochem 2014, 25, 81-90; DOI: 10.1016/j.jnutbio.2013.09.006.

138. Kassaian, N.;Aminorroaya, A.;Feizi, A.;Jafari, P.Amini, M., The effects of probiotic and synbiotic supplementation on metabolic syndrome indices in adults at risk of type 2 diabetes: study protocol for a randomized controlled trial. Trials 2017, 18, 148; DOI: 10.1186/s13063-017-1885-8. 
139. Saez-Lara, M.J.;Robles-Sanchez, C.;Ruiz-Ojeda, F.J.;Plaza-Diaz, J.Gil, A., Effects of Probiotics and Synbiotics on Obesity, Insulin Resistance Syndrome, Type 2 Diabetes and Non-Alcoholic Fatty Liver Disease: A Review of Human Clinical Trials. Int $J$ Mol Sci 2016, 17; DOI: 10.3390/ijms17060928.

140. Furrie, E.;Macfarlane, S.;Kennedy, A.;Cummings, J.H.;Walsh, S.V.;O'Neil D, A.Macfarlane, G.T., Synbiotic therapy (Bifidobacterium longum/Synergy 1) initiates resolution of inflammation in patients with active ulcerative colitis: a randomised controlled pilot trial. Gut 2005, 54, 242-9; DOI: 10.1136/gut.2004.044834.

141. Eslamparast, T.;Poustchi, H.;Zamani, F.;Sharafkhah, M.;Malekzadeh, R.Hekmatdoost, A., Synbiotic supplementation in nonalcoholic fatty liver disease: a randomized, double-blind, placebo-controlled pilot study. Am J Clin Nutr 2014, 99, 535-42; DOI: 10.3945/ajcn.113.068890.

142. Malaguarnera, M.;Vacante, M.;Antic, T.;Giordano, M.;Chisari, G.;Acquaviva, R.;Mastrojeni, S.;Malaguarnera, G.;Mistretta, A.;Li Volti, G.Galvano, F., Bifidobacterium longum with fructooligosaccharides in patients with non alcoholic steatohepatitis. Dig Dis Sci 2012, 57, 545-53; DOI: 10.1007/s10620-011-1887-4.

143. Mofidi, F.;Poustchi, H.;Yari, Z.;Nourinayyer, B.;Merat, S.;Sharafkhah, M.;Malekzadeh, R.Hekmatdoost, A., Synbiotic supplementation in lean patients with non-alcoholic fatty liver disease: a pilot, randomised, double-blind, placebo-controlled, clinical trial. Br J Nutr 2017, 117, 662-668; DOI: 10.1017/s0007114517000204.

144. Asgharian, A.;Askari, G.;Esmailzade, A.;Feizi, A.Mohammadi, V., The Effect of Symbiotic Supplementation on Liver Enzymes, C-reactive Protein and Ultrasound Findings in Patients with Non-alcoholic Fatty Liver Disease: A Clinical Trial. Int J Prev Med 2016, 7, 59; DOI: 10.4103/2008-7802.178533.

145. Goffredo, M.;Mass, K.;Parks, E.J.;Wagner, D.A.;McClure, E.A.;Graf, J.;Savoye, M.;Pierpont, B.; Cline, G.Santoro, N., Role of Gut Microbiota and Short Chain Fatty Acids in Modulating Energy Harvest and Fat Partitioning in Youth. J Clin Endocrinol Metab 2016, 101, 4367-4376; DOI: 10.1210/jc.2016-1797.

146. Zhou, J.;Gao, S.;Chen, J.;Zhao, R.Yang, X., Maternal sodium butyrate supplement elevates the lipolysis in adipose tissue and leads to lipid accumulation in offspring liver of weaning-age rats. Lipids Health Dis 2016, 15, 119; DOI: 10.1186/s12944-016-0289-1.

147. Zhou, D.;Pan, Q.;Xin, F.Z.;Zhang, R.N.;He, C.X.;Chen, G.Y.;Liu, C.;Chen, Y.W.Fan, J.G., Sodium butyrate attenuates high-fat diet-induced steatohepatitis in mice by improving gut microbiota and gastrointestinal barrier. World J Gastroenterol 2017, 23, 60-75; DOI: 10.3748/wjg.v23.i1.60.

148. Jernberg, C.;Lofmark, S.;Edlund, C.Jansson, J.K., Long-term ecological impacts of antibiotic administration on the human intestinal microbiota. ISME J 2007, 1, 56-66; DOI: 10.1038/ismej.2007.3.

149. Wu, W.-C., Small intestinal bacteria overgrowth decreases small intestinal motility in the NASH rats. World J Gastroenterol 2008, 14, 313; DOI: 10.3748/wjg.14.313.

150. Gangarapu, V.;Ince, A.T.;Baysal, B.;Kayar, Y.;Kilic, U.;Gok, O.;Uysal, O.Senturk, H., Efficacy of rifaximin on circulating endotoxins and cytokines in patients with nonalcoholic fatty liver disease. Eur J Gastroenterol Hepatol 2015, 27, 840-5; DOI: 10.1097/meg.0000000000000348.

151. Singh, R.Sripada, L., Side effects of antibiotics during bacterial infection: mitochondria, the main target in host cell. Mitochondrion 2014, 16, 50-4; DOI: 10.1016/j.mito.2013.10.005. 
152. Zhong, L.J.;Xie, Z.S.;Yang, H.;Li, P.Xu, X.J., Moutan Cortex and Paeoniae Radix Rubra reverse high-fat-diet-induced metabolic disorder and restore gut microbiota homeostasis. Chin J Nat Med 2017, 15, 210-219; DOI: 10.1016/s1875-5364(17)30037-7.

153. Xu, J.;Chen, H.B.Li, S.L., Understanding the Molecular Mechanisms of the Interplay Between Herbal Medicines and Gut Microbiota. Med Res Rev 2017, 37, 1140-1185; DOI: 10.1002/med.21431.

154. Hua, W.;Ding, L.;Chen, Y.;Gong, B.;He, J.Xu, G., Determination of berberine in human plasma by liquid chromatography-electrospray ionization-mass spectrometry. J Pharm Biomed Anal 2007, 44, 931-7; DOI: 10.1016/j.jpba.2007.03.022.

155. Zhang, X.;Zhao, Y.;Zhang, M.;Pang, X.;Xu, J.;Kang, C.;Li, M.;Zhang, C.;Zhang, Z.;Zhang, Y.;Li, X.;Ning, G.Zhao, L., Structural changes of gut microbiota during berberine-mediated prevention of obesity and insulin resistance in high-fat diet-fed rats. PLoS One 2012, 7, e42529; DOI: 10.1371/journal.pone.0042529.

156. Li, C.;He, J.Z.;Zhou, X.D.Xu, X., [Berberine regulates type 2 diabetes mellitus related with insulin resistance]. Zhongguo Zhong Yao Za Zhi 2017, 42, 2254-2260; DOI: 10.19540/j.cnki.cjcmm.20170307.014.

157. Xu, J.H.;Liu, X.Z.;Pan, W.Zou, D.J., Berberine protects against diet-induced obesity through regulating metabolic endotoxemia and gut hormone levels. Mol Med Rep 2017, 15, 2765-2787; DOI: $10.3892 / \mathrm{mmr} .2017 .6321$.

158. Cao, Y.;Pan, Q.;Cai, W.;Shen, F.;Chen, G.Y.;Xu, L.M.Fan, J.G., Modulation of Gut Microbiota by Berberine Improves Steatohepatitis in High-Fat Diet-Fed BALB/C Mice. Arch Iran Med 2016, 19, 197-203; DOI: 0161903/aim.008.

159. Xie, W.;Gu, D.;Li, J.;Cui, K.Zhang, Y., Effects and action mechanisms of berberine and Rhizoma coptidis on gut microbes and obesity in high-fat diet-fed C57BL/6J mice. PLoS One 2011, 6, e24520; DOI: 10.1371/journal.pone.0024520.

160. Lin, P.;Lu, J.;Wang, Y.;Gu, W.;Yu, J.Zhao, R., Naturally Occurring Stilbenoid TSG Reverses NonAlcoholic Fatty Liver Diseases via Gut-Liver Axis. PLoS One 2015, 10, e0140346; DOI: 10.1371/journal.pone.0140346.

161. Varshney, P.Dey, C.S., Resveratrol regulates neuronal glucose uptake and insulin sensitivity via P21-activated kinase 2 (PAK2). Biochem Biophys Res Commun 2017, 485, 372-378; DOI: 10.1016/j.bbrc.2017.02.070.

162. Qiao, Y.;Sun, J.;Xia, S.;Tang, X.;Shi, Y.Le, G., Effects of resveratrol on gut microbiota and fat storage in a mouse model with high-fat-induced obesity. Food Funct 2014, 5, 1241-9; DOI: 10.1039/c3fo60630a.

163. Yin, X.;Peng, J.;Zhao, L.;Yu, Y.;Zhang, X.;Liu, P.;Feng, Q.;Hu, Y.Pang, X., Structural changes of gut microbiota in a rat non-alcoholic fatty liver disease model treated with a Chinese herbal formula. Syst Appl Microbiol 2013, 36, 188-96; DOI: 10.1016/j.syapm.2012.12.009.

164. Feng, Q.;Liu, W.;Baker, S.S.;Li, H.;Chen, C.;Liu, Q.;Tang, S.;Guan, L.;Tsompana, M.;Kozielski, R.;Baker, R.D.;Peng, J.;Liu, P.;Zhu, R.;Hu, Y.Zhu, L., Multi-targeting therapeutic mechanisms of the Chinese herbal medicine QHD in the treatment of non-alcoholic fatty liver disease. Oncotarget 2017, 8, 27820-27838; DOI: 10.18632/oncotarget.15482.

165. Hussain, A.;Yadav, M.K.;Bose, S.;Wang, J.H.;Lim, D.;Song, Y.K.;Ko, S.G.Kim, H., Daesiho-Tang Is an Effective Herbal Formulation in Attenuation of Obesity in Mice through Alteration of Gene Expression and Modulation of Intestinal Microbiota. PLoS One 2016, 11, e0165483; DOI: 10.1371/journal.pone.0165483. 
166. Wang, J.;Zhang, H.;Chen, X.;Chen, Y.;MenghebiligeBao, Q., Selection of potential probiotic lactobacilli for cholesterol-lowering properties and their effect on cholesterol metabolism in rats fed a high-lipid diet. J Dairy Sci 2012, 95, 1645-54; DOI: 10.3168/jds.2011-4768.

167. An, H.M.;Park, S.Y.;Lee, D.K.;Kim, J.R.;Cha, M.K.;Lee, S.W.;Lim, H.T.;Kim, K.J.Ha, N.J., Antiobesity and lipid-lowering effects of Bifidobacterium spp. in high fat diet-induced obese rats. Lipids Health Dis 2011, 10, 116; DOI: 10.1186/1476-511x-10-116.

168. Gauffin Cano, P.;Santacruz, A.;Moya, A.Sanz, Y., Bacteroides uniformis CECT 7771 ameliorates metabolic and immunological dysfunction in mice with high-fat-diet induced obesity. PLoS One 2012, 7, e41079; DOI: 10.1371/journal.pone.0041079.

169. Loguercio, C.;Federico, A.;Tuccillo, C.;Terracciano, F.;D'Auria, M.V.;De Simone, C.Del Vecchio Blanco, C., Beneficial effects of a probiotic VSL \#3 on parameters of liver dysfunction in chronic liver diseases. J Clin Gastroenterol 2005, 39, 540-3.

170. Al-Muzafar, H.M.Amin, K.A., Probiotic mixture improves fatty liver disease by virtue of its action on lipid profiles, leptin, and inflammatory biomarkers. BMC Complement Altern Med 2017, 17, 43; DOI: 10.1186/s12906-016-1540-z.

171. Famouri, F.;Shariat, Z.;Hashemipour, M.;Keikha, M.Kelishadi, R., Effects of Probiotics on Nonalcoholic Fatty Liver Disease in Obese Children and Adolescents. J Pediatr Gastroenterol Nutr 2017, 64, 413-417; DOI: 10.1097/mpg.0000000000001422.

172. Wong, V.W.;Won, G.L.;Chim, A.M.;Chu, W.C.;Yeung, D.K.;Li, K.C.Chan, H.L., Treatment of nonalcoholic steatohepatitis with probiotics. A proof-of-concept study. Ann Hepatol 2013, 12, 25662.

173. Nabavi, S.;Rafraf, M.;Somi, M.H.;Homayouni-Rad, A.Asghari-Jafarabadi, M., Effects of probiotic yogurt consumption on metabolic factors in individuals with nonalcoholic fatty liver disease. $J$ Dairy Sci 2014, 97, 7386-93; DOI: 10.3168/jds.2014-8500.

174. Ejtahed, H.S.;Mohtadi-Nia, J.;Homayouni-Rad, A.;Niafar, M.;Asghari-Jafarabadi, M.;Mofid, V.Akbarian-Moghari, A., Effect of probiotic yogurt containing Lactobacillus acidophilus and Bifidobacterium lactis on lipid profile in individuals with type 2 diabetes mellitus. J Dairy Sci 2011, 94, 3288-94; DOI: 10.3168/jds.2010-4128.

175. Yuan, Y.;Sun, Z.M.;Zhang, Y.;Liang, F.F.He, X.X., [Influence of gut microecology on the pathogenesis and treatment of nonalcoholic fatty liver disease]. Zhonghua Gan Zang Bing Za Zhi 2016, 24, 375-9; DOI: 10.3760/cma.j.issn.1007-3418.2016.05.012.

176. Xu, J.;Lian, F.;Zhao, L.;Zhao, Y.;Chen, X.;Zhang, X.;Guo, Y.;Zhang, C.;Zhou, Q.;Xue, Z.;Pang, $X$.Tong, X., Structural modulation of gut microbiota during alleviation of type 2 diabetes with a Chinese herbal formula. ISME J 2015, 9, 552-62; DOI: 10.1038/ismej.2014.177. 